\title{
MEDIUM-TERM DETERMINANTS OF CURRENT ACCOUNTS IN INDUSTRIAL AND DEVELOPING COUNTRIES: AN EMPIRICAL EXPLORATION
}

\author{
Menzie Chinn \\ Eswar S. Prasad \\ Working Paper 7581 \\ http://www.nber.org/papers/w7581 \\ NATIONAL BUREAU OF ECONOMIC RESEARCH \\ 1050 Massachusetts Avenue \\ Cambridge, MA 02138 \\ March 2000
}

We are grateful to Tamim Bayoumi, Hamid Faruqee, Peter Isard, Lori Kletzer, Philip Lane, Gian Maria Milesi-Ferretti, Assaf Razin and numerous other colleagues and seminar participants for comments and helpful discussions and to Sarma Jayanthi for research assistance. The views expressed herein are those of the authors and are not necessarily those of the IMF or the National Bureau of Economic Research.

(C) 2000 by Menzie Chinn and Eswar S. Prasad. All rights reserved. Short sections of text, not to exceed two paragraphs, may be quoted without explicit permission provided that full credit, including $\odot$ notice, is given to the source. 
Medium-Term Determinants of Current Accounts in Industrial and Developing

Countries: An Empirical Exploration

Menzie Chinn and Eswar S. Prasad

NBER Working Paper No. 7581

March 2000

JEL No. F32, F41

\begin{abstract}
This paper provides an empirical investigation of the medium-term determinants of current accounts for a large sample of industrial and developing countries. The analysis is based on a structural approach that highlights the roles of the fundamental macroeconomic determinants of saving and investment. Cross-section and panel regression techniques are used to characterize the properties of current account variation across countries and over time. We find that current account balances are positively correlated with government budget balances and initial stocks of net foreign assets. Among developing countries, measures of financial deepening are positively associated with current account balances while indicators of openness to international trade are negatively correlated with current account balances.
\end{abstract}

Menzie D. Chinn

Department of Economics

Social Sciences I

University of California, Santa Cruz

Santa Cruz, CA 95064

and NBER

chinn@cats.ucsc.edu
Eswar S. Prasad

Research Department

IMF

700 19th Street, N.W. Washington, DC 20431

eprasad@imf.org 


\section{Introduction}

The objective of this paper is to provide an empirical characterization of the determinants of current account balances for a large sample of industrial and developing countries. The approach taken here is to view the current account from the longer-run perspective of saving-investment balances. Thus, the roles of the "fundamental" determinants of saving and investment levels are emphasized rather than factors influencing the short-run dynamics of the current account. Using both cross-section and panel data estimation techniques and an extensive dataset that covers industrial and developing countries, we characterize the main determinants of medium-term current account variation across countries and over time.

The determinants of current account balances are of considerable interest in open economy macroeconomics. Alternative theoretical models have different predictions about the factors underlying current account dynamics and about the sign and magnitude of the relationships between current account fluctuations and these determinants. Hence, empirical analysis of the sort undertaken in this paper could help discriminate among competing theories.

Understanding the factors that influence medium-term fluctuations in the current account could have important policy implications as well. In particular, the notion of current account sustainability has come to be of considerable interest in the context of recent episodes of macroeconomic turbulence in many emerging markets. Although this paper does not directly address the question of current account sustainability, the analysis does provide an indication of the levels of current accounts that may be considered "normal" for a country, based on a number of its structural and macroeconomic attributes, including stage of development, demographic profile, the government budget balance etc.

In this paper, we take a uniform approach to analyzing the determinants of current account balances for industrial and developing countries. Since the world as a whole is a closed economy, there are obvious inter-relationships among the current account positions of industrial and developing countries. In our empirical work, we allow for differences in results across different groups of countries. However, rather than merely positing that these differences exist, we relate them to observed attributes of these countries. Our dataset is well suited for such an analysis since it covers a large and heterogeneous group of countries (18 industrial, 71 developing) over a relatively long time span (1971-1995). The empirical analysis in the paper 
also involves a rich set of potential determinants of current account variation--including many drawn from the literatures on the cross-country determinants of growth, saving, and investment--and an extensive battery of robustness tests for the main results.

This paper is related to a number of different strands of literature. One set of papers has explored, using different techniques and datasets, the determinants of saving for both industrial and developing countries (see, e.g., Schmidt-Hebbel, Webb and Corsetti, 1992; Edwards, 1995; Masson, Bayoumi and Samiei, 1997). Many of these papers have attempted to link national saving to structural determinants including levels of economic development, demographic profiles etc. Interestingly, a number of these studies include the current account as an independent variable that determines national saving. Thus, our approach is fundamentally different from this literature in that this paper views current account balances as the outcome of variations in structural and macroeconomic determinants that influence the saving-investment balance. A much smaller set of papers has examined the macroeconomic determinants of investment in developing countries (see, e.g., Serven, 1998). The literature on domestic investment in industrial countries is vast.

Current accounts have themselves, of course, been the subject of considerable research. One recent approach, represented by papers such as Ghosh (1995) and Ghosh and Ostry (1995), is the application of insights derived from the consumption-smoothing literature to the modeling of current account dynamics. Glick and Rogoff (1995) model the joint dynamics of investment and current accounts in response to productivity shocks (also see Nason and Rogers, 1999). They show that, for a sample of industrial countries, country-specific shocks rather than global shocks are important for current account fluctuations and also that the degree of persistence of a productivity shock affects the current account response in an important way. These sets of papers, however, focus largely on the short-run dynamics of the current account.

The more ambitious intertemporal approach to current account determination, as typified by the work of Razin (1995) and Obstfeld and Rogoff (1998), has attempted to extend dynamic optimizing models to the open economy context. An alternative structural approach to current account determination is adopted by Debelle and Faruqee (1996), who use a savinginvestment perspective to motivate empirical specifications that contain the "structural" determinants of current accounts. 
In this paper, we build upon the work of the authors cited above and, in particular, generalize the work of Debelle and Faruqee (1996) by extending the analysis to developing countries and by exploring a wider range of static and dynamic specifications. Although we use a variety of theoretical models to understand and interpret our results, we do not test any of these models or their predictions formally. Hence, the paper's objective is mainly to provide an empirical, but not entirely atheoretical, characterization of current account determinants that could be helpful for determining the empirical relevance of and for constructing more formal theoretical models. Our work is similar in some respects to that of Calderon, Chong and Loayza (1999) but our focus, unlike theirs, is on medium-term current account determination and our econometric methodologies are, therefore, quite different.

The next section of the paper contains a discussion of some data and econometric issues germane to the empirical modeling of current account dynamics. Results from cross-section regressions are presented in Section III and results from panel estimation are presented in Section IV. A variety of robustness tests for the main results are discussed in Section V. Concluding remarks are in Section VI.

\section{The Empirical Framework}

This section presents a selective overview of certain empirical issues that motivate the estimation framework used in this paper. A more detailed discussion of the theoretical effects of different variables on the current account is deferred until the next section.

The benchmark sample for our analysis covers both industrial and developing countries. The basic data set has annual data for 18 industrial and 71 developing countries and, for most countries in the sample, covers the period 1971-95. Variable definitions and data sources, along with the list of countries in the sample and country groupings, are presented in the Appendix. The dependent variable in most of the analysis is the current account balance, expressed as a ratio to GDP. A negative value of the dependent variable represents a current account deficit.

The empirical specifications used in the paper are generally of the following form:

$$
\left(\frac{C A}{G D P}\right)_{i t}=\alpha+\beta X_{i t}+\varepsilon_{i t}
$$


where the current account is expressed as a ratio to GDP in order to control for scale effects and $\mathrm{X}$ is a vector of independent variables that includes the government budget balance; relative income; dependency ratios; average GDP growth; terms of trade volatility; measures of capital controls; degree of openness; and financial deepening. For cross-section regressions, the time subscript is not relevant. The precise definitions of these variables and the predictions of different theoretical models about the signs and magnitudes of the relationships between these variables and current account balances will be discussed in later sections of the paper. Dummies for regional groupings of countries are also included in the estimation where indicated and, in the panel regressions, so are time dummies.

One potential problem with developing country data is the possibility of significant measurement error in relatively high frequency data, even at an annual frequency. To obviate any biases in our results arising from such measurement error, and since our interest is primarily in medium-term rather than short-term variations in current accounts, we construct a panel that contains non-overlapping 5-year averages of the data for each country. So, for instance, 25 annual observations for a particular country over the 1971-95 period would be compressed into 5 observations. This procedure also has the advantage of abstracting from short-run variations in current accounts and related variables, which are of lesser interest for the purposes of the analysis in this paper. We later test the robustness of our results to this compression of the data by recomputing all of the estimates using the underlying annual data.

Table 1 presents a variance decomposition for this panel data set that indicates how much of the variation in the relevant variables is attributable to variation across countries and over time, respectively. Certain variables such as current account balances and government budget balances vary substantially across countries and, within each country, over time. In contrast, other variables including relative income and net foreign asset positions vary markedly across countries but are relatively more stable over time within countries. There are some differences in the contributions of within- and between-country effects across the industrial and developing country samples, but the relative importance of these two effects for the total variation in each variable is quite similar across the two samples. The main result to be taken from this table is that many of the dependent and independent variables of interest for this study vary quite markedly in both the cross-section and time-series dimensions. 
An important point to note here is that our primary interest is in low-frequency current account variation. Hence, we do not attempt to distinguish between the effects of temporary and permanent shocks and among different sources of shocks. These distinctions are potentially very important for modeling short-run dynamics and for disentangling short-run and long-run dynamics of the current account. ${ }^{1}$ Given the frequency of the data that we work with, the interpretation of our results is less influenced by issues concerning the sources and persistence of the underlying shocks.

\section{Cross-Section Results}

In this section, we use cross-sectional specifications to examine the determinants of the levels of current account balances. Our goal in this section is to provide a broad-brush characterization of the structural factors that could be important for determining cross-country variation in current account positions.

We first examine the results from OLS regressions for the full-sample averages of the independent variable and each of the dependent variables for each country. In principle, these regressions highlight the factors that are relevant for current account determination at very low frequencies. The results are presented in Table 2. The first column shows the results for all countries, while the remaining columns show the results from regressions run separately for industrial and developing countries, respectively. Since many of the results were sensitive to the inclusion of African countries, we also report results for the full sample and for the developing country sample excluding the African countries.

A result that appears to be relatively robust across country groupings is that the government budget balance is positively related to the current account balance. In other words, higher levels of public saving across countries tend to be associated with larger current account surpluses (or smaller current account deficits). This is an interesting result but, since budget

\footnotetext{
${ }^{1}$ Glick and Rogoff (1995), Lee and Chinn (1998) and Prasad (1999) show how the sources of shocks and their persistence can affect the dynamics of trade and current account balances. Calderon, Chong and Loayza (1999) try to differentiate between the effects of permanent and transitory shocks on annual current account variation in developing countries.
} 
balances vary quite substantially over time within countries, we just note the robustness of this result here and investigate it further in the next section.

Next, we examine the role of an important "initial condition"- - the beginning-of-sample stock of net foreign assets (NFA). In order to reduce the effects of measurement error, we use the average value of the NFA to GDP ratio in the first five years of the sample for each country. ${ }^{2}$ The initial stock of NFA would, in principle, be expected to be negatively related to the current account. For instance, from an intertemporal perspective, a country that had a significant stock of net foreign liabilities (NFL) relative to its GDP would eventually have to run surpluses, at least on its trade balance, in order to pay off its liabilities or, at the minimum, would need to run smaller current account deficits (as a ratio to GDP) in order to stabilize its NFL/GDP ratio. However, even in a sample that spans two-and-a-half decades, this long-run effect could be overwhelmed by other factors.

Figure 1, which plots initial NFA/GDP ratios versus average current account balances, hints at a positive relationship between these two variables, especially among the industrial countries. These scatter plots should be interpreted with caution since they show only unconditional correlations between two variables, unlike the regression results which control for a number of other variables. The results in the first column of Table 2 do reveal a strong positive conditional relationship between the stock of NFA and the current account for the full sample. An examination of the other columns of this table shows that, in the cross section, this result is driven largely by industrial countries. In other words, industrial countries that have a relatively large stock of NFA to begin with tend to run larger current account surpluses. While the coefficient is also positive for developing countries, it is much smaller and not significant.

\footnotetext{
${ }^{2}$ As a robustness check, we tried replacing the NFA variable with the measure of net external debt taken from the World Bank saving database. In principle, these variables should be similar. However, the correlation between these two variables turned out be quite small and, perhaps because of greater measurement error in the debt variable, the coefficient on the external debt to GDP ratio was not significant in some specifications (the sample sizes were smaller since the latter variable was available only for a subset of the countries in our full sample). An effort is underway by a consortium of international organizations (BIS, OECD, IMF, World Bank) to improve the quality and consistency of cross-country external debt data but these improved data are currently available only for a very limited period.
} 
The "stages of development" hypothesis for the balance of payments suggests that, as countries move from a low to an intermediate stage of development, they typically import capital and, therefore, run current account deficits (see Roldos, 1996, for a survey of recent work on this topic). Over time, as they reach an advanced stage of development, countries run current account surpluses in order to pay off accumulated external liabilities and also to export capital to less advanced economies. This is in some ways a rough analogue to the permanent income life-cycle hypothesis, but at the country rather than individual level. Various models of the "big push" and "take off" describe the factors that could determine the timing of this transition but the threshold at which this transition occurs, and especially the point at which it influences the current account position, is finally an empirical matter. This is, of course, a longterm view of current account determination but using a cross-section of countries distributed over a wide range in terms of stage of development provides an indirect test of the empirical validity of this hypothesis.

To capture stage of development effects, we include relative per capita income and its square in the regressions. In each year, relative per capita income is measured as the ratio of domestic per capita income to U.S. per capita income. Incomes for countries other than the U.S. are converted into U.S. dollars using purchasing power parity exchange rates. The squared term allows for possible nonlinearities in the relationship between relative per capita income and current account positions. In particular, this term captures the empirical relevance of the stages of development hypothesis which predicts a U-shaped relationship between the current account balance and the stage of development, as measured by relative per capita output. ${ }^{3}$

For the full sample, the coefficient on the relative income term is positive and the coefficient on the quadratic term is negative, with both coefficients being strongly statistically significant. Taken together, these coefficients suggest a pattern which is the opposite of that predicted by the stage of development hypothesis. This pattern, however, appears to be driven mainly by the industrial countries in the sample (column 3). The coefficients on the relative

\footnotetext{
${ }^{3}$ An interesting issue that arises here is whether the relative income level is the appropriate measure to capture a country's stage of development. As noted below, we also control for growth rates of output, which, however, could also proxy for other factors. This issue is discussed in more detail in the next section.
} 
income terms are not significant for the developing country sample separately (columns 4 and 5). Figure 2 provides a graphical representation of the cross-sectional relationship between the current account to GDP ratio and relative income. The developing and industrial country groups (the latter set of countries labeled with upper case letters) form two clusters (partly overlapping) on this scatter plot. Mechanically, it is easy to see from this figure why a regression that attempts to fit points in both clusters yields the signs it does on the level and quadratic relative income terms. Thus, in our sample, the cross section regressions do not provide evidence in favor of the stages of development hypothesis for explaining levels of current account positions across countries. ${ }^{4}$

An important structural determinant of domestic saving is likely to be the demographic profile of the population. One would expect the size of the dependent population relative to the working-age population to be negatively correlated with aggregate domestic saving. From the perspective of current account determination, however, demographic profiles should be important only insofar as they differ across countries and, thereby, influence cross-country differences in saving. Further, there could be differences in saving patterns depending on the fractions of the total population that are comprised of young and old dependents. To capture these differences, we construct young and old dependency ratios separately and express both these ratios relative to the respective sample averages across all countries.

The results indicate that higher relative dependency ratios are indeed associated with smaller current account surpluses (or larger deficits) for some of the country groups. There are differences in the magnitudes of the effects of dependency ratios for the young and the old; only the youth dependency ratio has a significant negative effect on current accounts among developing countries. Although few of the estimated coefficients are statistically significant, they have the same signs but are larger in absolute magnitudes than the coefficients on the total dependency ratio reported by Masson, Bayoumi, and Samiei (1998) in their study of the

\footnotetext{
${ }^{4}$ Debelle and Faruqee (1996) report similar cross-section results for a sample including industrial and a few developing countries. They, too, note the instability of these coefficient estimates across specifications. We experimented with the inclusion of higher order polynomials of relative income in the regressions, but their coefficients were not statistically significant and did not change any of the results.
} 
determinants of national saving, using annual data for industrial and developing countries. We interpret this as indicating that demographic factors play a more important role in lowfrequency rather than high-frequency current account variation and that national saving is the channel through which dependency ratios affect current account positions.

A potentially important determinant of saving, that has been emphasized in particular by Edwards (1995), is "financial deepening." This is usually proxied by the ratio of a monetary aggregate such as M2 to GDP. Although he finds that this variable is positively correlated with national saving rates, Edwards points out that the interpretation of the results using this variable could be complicated. The traditional interpretation of this variable as a measure of the depth and sophistication of the financial system suggests that financial deepening could induce more saving. Alternatively, this variable could be viewed as a proxy for the borrowing constraint faced by individuals in an economy, and could therefore actually be associated with lower levels of private saving. Furthermore, the effects of financial deepening on domestic investment, which is the other side of the saving-investment balance, are even less obvious. Although we do not have a strong prior on the relationship between financial deepening and the current account, we include this variable in our cross-country regressions.

The results indicate that the average level of financial deepening does have a significant and robustly positive effect on the current account in developing countries but not in industrial countries. This is an interesting result but we defer a more detailed analysis of this result to the next section, since the extent of financial deepening may have changed substantially over the last three decades, especially for developing countries.

The terms of trade is an important determinant of short-term fluctuations in the current account. In particular, the volatility of the terms of trade could influence low-frequency current account variation for a number of reasons. ${ }^{5}$ Agents in economies that face more volatile terms of trade might tend to save more for precautionary reasons in order to smooth their consumption streams in the face of volatile income flows. However, the effects of terms of trade volatility on investment and, hence, on the current account, are less clear. Countries with

\footnotetext{
${ }^{5}$ The level of the terms of trade would also be expected to influence the evolution of the trade balance and the current account over time. However, since the terms of trade variable is available only as in index, we were unable to use this variable in cross-country analysis.
} 
more volatile terms of trade may be less attractive for international capital. On the other hand, authors such as Aizenman (1994) have argued that multinationals tend to diversify their production base across countries with volatile terms of trade in order to have the flexibility to exploit terms of trade movements that are favorable to them.

The cross-country results do reveal a significant role for terms of trade volatility in current account determination for developing countries excluding Africa. For these countries, higher terms of trade volatility is associated with larger current account surpluses, consistent with the notion of this volatility inducing more precautionary saving and/or lower investment. For industrial countries, on the other hand, terms of trade volatility appears to be negatively correlated with current account balances.

Another variable that could influence both saving and investment is the growth rate of aggregate output. The effects of GDP growth rates on low frequency saving behavior are not clear-cut. This relationship depends largely on the implications of GDP growth rates, as perceived by households, for their permanent income. For instance, if current high growth rates of GDP were to be interpreted as signaling increases in permanent income, then saving rates as a proportion of current income could, according to the life cycle permanent income hypothesis, actually decline. On the other hand, increases in GDP growth rates that are viewed as being transitory, would tend to raise saving rates. Furthermore, these outcomes for aggregate household saving would also depend on the fraction of households that are liquidity constrained. High rates of GDP growth presumably also reflect high rates of productivity growth and would, therefore, be expected to be associated with higher levels of investment and, presumably, inflows of capital in search of higher rates of return. Again, the net effects of these influences on current account balances are not obvious.

Our regressions show that there is no clear relationship between average output growth and current account balances for the full sample. There is, however, a strong positive relationship between these variables for the industrial countries in our sample, consistent with the observation that advanced countries that had relatively high growth rates over the last three decades have generally been net providers of capital to other economies.

Among developing countries there appears to be a negative relationship between the openness ratio, measured as the sum of exports and imports to GDP, and current account 
balances. The degree of openness could well be correlated with other attributes that make a country attractive to foreign capital. In particular, the capacity that more open economies have to generate foreign exchange earnings through exports might signal a better ability to service external debt. ${ }^{6}$ Since there have been large increases in the degree of openness to international trade among both industrial and developing countries over the last three decades, we explore the relationship between openness and current accounts in greater detail in the next section.

We also examined the role of capital controls in current account determination. These results are also not straightforward to interpret. Capital controls are often viewed as a negative indicator of a country's ability to manage its external balance. The introduction of capital controls might result from a desire to prevent capital flight triggered by current account deficits, but the imposition of such controls could result in smaller current account deficits since external financing for subsequent current account deficits may be limited. Hence, issues of causality and timing complicate this analysis. Nevertheless, as a first pass, we included indicator variables that capture the existence and severity of controls on capital flows related to current account and capital account transactions. These binary variables take the value of unity when there are significant restrictions present and zero otherwise.

Except in the case of the industrial country sample, we do not find a statistically significant association between capital controls and current accounts. Since capital controls have varied over time for many of the countries in our sample, it is possible that the crosssection results mask the relationship between these variables. We investigate this further in the next section.

To summarize the key results from this section, government budget balances and indicators of financial deepening appear to be positively correlated with current account balances in the cross section for developing countries. Dependency ratios and indicators of openness to international trade, on the other hand, appear to be negatively correlated with average current account positions. For industrial countries, initial NFA positions and average output growth rates have positive cross-sectional correlations with current account balances.

\footnotetext{
${ }^{6}$ Consistent with this result, Lane (1997) reports a positive association between trade openness and the level of external debt among developing countries.
} 


\section{Panel Estimates}

An obvious concern with the cross-section results discussed thus far is that important dynamic patterns in the data could be missed by taking averages over long periods of time. Hence, we now adopt a panel approach that allows us to characterize higher frequency variations in current account balances. In other words, we exploit both the cross section and time series aspects of the data to understand variation across countries and over time in current account balances. As discussed earlier, we work with a panel data set that contains nonoverlapping 5-year averages of the data for each country. We later test the robustness of our results to this compression of the data. We use OLS specifications for our baseline results and later test the sensitivity of the results to the choice of empirical specification.

Table 3 shows results from panel OLS regressions for different groupings of countries. Since we found some of these panel results also to be sensitive to the inclusion of the African countries, we report separate sets of results with and without the African countries included, both for the full sample and for the developing country sample. We also experimented with the inclusion of other regional dummies (for continents as well as for specific groups such as East Asian countries). These dummies were generally neither individually nor jointly significant for most of the specifications discussed below. One exception was the dummy for oil-exporting countries, which was generally positive and significant, reflecting the fact that oil-exporting countries typically have more favorable current account positions on average. Hence, the results reported in Table 3 are from regressions that include this dummy. ${ }^{7}$

An important consideration in understanding current account dynamics is the role of international capital flows. Especially for developing countries, the ability to run current account deficits could well be affected by industrial countries' willingness to finance those deficits through capital flows. These patterns of capital flows could be influenced by a number of factors including macroeconomic conditions in industrial countries and have indeed fluctuated significantly over time (see, e.g., Bosworth and Collins, and references therein). We return to a more detailed examination of this issue later. As a practical matter, however, we

\footnotetext{
${ }^{7}$ Wald tests confirmed that the hypothesis of homogeneity of coefficients across the different groupings of countries shown in the table could be rejected.
} 
need to address this issue in our estimation and do so by including time dummies for each 5year period in our regressions. These time dummies were jointly significant in all of the regressions discussed in this section. We report in the results the specific time dummies that were individually significant.

One of the striking results that carries over from the cross-sectional regressions is the strong positive relationship between current account and government budget balances. However, the coefficient is no longer statistically significant for industrial countries. The estimated coefficient in column 4 suggests that, for the full sample of developing countries, a 1 percentage point increase in the government budget balance is associated with about a 0.4 percentage point increase in the current account to GDP ratio. One interpretation of the coefficient estimates is that, in developing countries, private saving provides a significant but not complete Ricardian offset to changes in public saving. This is consistent with Edwards's (1995) result that in developing countries private saving, as a ratio to GDP, declines by about 0.6 percentage points when the ratio of government saving to GDP increases by 1 percentage point. The relationship that we find between government budget balances and current account balances is also consistent with a large class of theoretical models. As noted by Obstfeld and Rogoff (1998), for instance, overlapping generations models suggest that government budget deficits tend to induce current account deficits by redistributing income from future to present generations. The positive correlation between budget and current account balances is reminiscent of the "twin deficits" discussion that was popular in the 1980s, although in our sample we find this relationship to be stronger for developing than for industrial countries.

Next, we examine the relationship between current accounts and one of the key initial conditions that would be expected to influence their determination-the existing stock of net foreign assets or liabilities. For the panel regressions, the initial stock of NFA refers to the NFA/GDP ratio in the first year of the 5-year period over which the current account and the independent variables are averaged. The results indicate a robust positive association between initial NFA to GDP ratios and current account balances. For the combined sample of industrial and developing countries, this result is as strong as in the cross-section regressions. In the subsample panel regressions, however, the result comes through strongly for the developing countries as well. Among the industrial countries, this result again reflects the fact that 
countries with large NFA positions over the sample period, such as Japan and Switzerland, have tended to run current account surpluses while, for certain countries such as the United States, there appears to have been a negative relationship between existing NFA stocks and current account positions. ${ }^{8}$

We conjecture that, among developing countries, this result indicates that countries that have tended to run current account deficits, and that have consequently built up a stock of NFL, tend to be countries that have better access to capital markets and that are favored by international investors for a variety of reasons. Hence, despite their existing stock of NFL, international investors are more willing to finance larger current account deficits for these countries. This, in turn, could reflect the fact that these countries have higher levels of productivity and, consequently, higher rates of return to capital. ${ }^{9}$ Further, large flows of capital from industrial to developing countries are a relatively recent phenomenon. Therefore, in our limited sample, this effect could dominate the fact that, from a longer-term perspective, a net outflow of capital from developing countries could eventually be required to pay off (or, at least, stabilize as a ratio to GDP) the stock of external liabilities. ${ }^{10}$

\footnotetext{
${ }^{8}$ When we replaced the initial NFA/GDP ratio variable used here (based on the value of this variable in the first year of the five years averaged for a particular observation) with the NFA/GDP ratio used in the cross-section regressions (the average of the NFA/GDP ratio in the first five years of the full sample for each country), the results were similar to those discussed here, but only when the African countries were excluded. For the full developing country sample, the other coefficients did not change much but the coefficient on the initial NFA to GDP ratio, although still positive, was less strongly significant.

${ }^{9}$ An alternative explanation is that the perception among international investors of implicit guarantees of bailouts for certain countries could induce a moral hazard problem. This would be reflected in perverse feedback effects, whereby countries with high external debt get further access to international capital. Lane (1998) documents a strong positive relationship between the levels of external debt and output among developing economies and notes that this finding is consistent with models of international credit rationing.

${ }^{10}$ Kraay and Ventura (2000) argue that the sign of the current account response to transitory income shocks depends on the share of foreign assets in a country's total assets. However, since our use of 5-year averaged data would be expected to smooth out transitory income shocks, this explanation might be less relevant for our medium-term results.
} 
In the first three columns of the table, the coefficients on the relative income terms are not significant. For developing countries, the relative income effect is negative and the coefficient on the relative income quadratic term is positive, consistent with the implications of the stages of development hypothesis. However, only the coefficients on the quadratic terms in columns 4 and 5 are significant, yielding but limited support for this hypothesis.

The coefficients on the dependency ratios indicate that higher relative dependency ratios are associated with lower current account balances. The effect is stronger for industrial countries. We find a similar result for developing countries as well, although only the coefficient on the relative youth dependency ratio is significant and this too only when we exclude African countries from the sample.

In the panel regressions for the full sample, as was the case in the cross-section regressions, the financial deepening variable has a clear positive association with current account balances. As in the cross-section regressions, we find that this result comes through strongly for all samples that include developing countries. The estimated coefficients are in line with those reported by authors such as Edwards (1995), who have examined the effects of this variable on private saving. Thus, we conjecture that private saving is again the channel through which financial deepening influences the current account.

Terms of trade volatility does have a significant positive relationship with the current account balance for the developing country sample that excludes Africa. This result comes through as strongly as in the cross-section regressions and is clearly indicative of the effect of overall macroeconomic uncertainty on private saving in developing countries. Further, as noted by Serven (1998), there is also some evidence that investment in developing countries is negatively affected by terms of trade volatility. Average income growth, on the other hand, appears to bear little relationship to the current account. ${ }^{11}$

We find that the degree of openness of an economy is negatively related to its current account position, although there appears to be no association between these two variables among industrial countries; the result is driven largely by the developing countries. The

\footnotetext{
${ }^{11}$ Although their relationship to current accounts is not obvious, we also tried including other macroeconomic variables such as average inflation rates but they did not enter significantly into any of these regressions.
} 
openness variable might well be indicative of attributes such as liberalized trade that make a country attractive to foreign investment. Further, international trade often serves as an important vehicle for transfers of technology to developing countries. Thus, countries with more exposure to international trade tend to be relatively more attractive to foreign capital, allowing them to undertake more investment and to finance the resulting current account deficits with capital from abroad. Also, as noted earlier, more open economies are likely to have a better ability to service their external debt through export earnings.

In general, capital controls do not appear to have played a significant role in current account determination (conditional on other variables examined here). ${ }^{12}$ The coefficients on the indicator variables that capture various forms of capital controls are generally not statistically significant. In part, as noted earlier, the absence of an association between these variables could reflect the existence of two opposing effects. On the one hand, one would expect countries with capital controls to have relatively limited access to international capital and, therefore, to perforce run smaller current account deficits. However, an alternative possibility is that the capital controls could have resulted from attempts to stave off the consequences of a legacy of chronic current deficits. As an empirical matter, the direction of causation is apparently far from clear even in a panel context.

\section{IV.1 Outliers and Threshold Effects}

To check if our baseline results are sensitive to outliers, we performed a variety of experiments. To conserve space, we only summarize the main results here. First, we excluded all observations for which the dependent variable had a value smaller than -0.10 (i.e., a current account deficit greater than 10 percent of GDP). This cut the total sample from 305 to 269 observations (only 3 of the eliminated observations were for industrial countries). Virtually all of the coefficients that had been significant before retained their statistical significance with this smaller sample, although the coefficients on the government budget balance and the

${ }^{12}$ To check if any of the other variables in the regressions could be picking up the effects of the capital controls, we tried a variety of specifications that excluded various combinations of the openness indicators, financial deepening variables etc. None of these specifications yielded a statistically significant coefficient on either of the indicators of capital controls. 
NFA/GDP ratio were slightly smaller. In fact, the coefficients on certain variables such as the young dependency ratio and terms of trade volatility became even more strongly significant for developing countries and there were more significant time dummies when this limited sample was used. Second, we used a tighter screen and excluded observations for which the dependent variable was smaller than -0.05 (about a third of all observations). Interestingly, even with this markedly smaller sample, the main results were preserved, although there was the expected increase in standard errors for most coefficients.

We also examined the possibility of the results being driven by outliers in key variables such as the government budget balance and the NFA/GDP ratio. We created a dummy variable that took the value 1 if the budget balance was smaller than -0.05 (i.e., a budget deficit greater than 5 percent of GDP). Neither this dummy nor its interaction with the government budget balance variable were statistically significant and the effects on the estimated coefficients on the budget balance and other variables were very small. Similarly, we created a dummy for values of the NFA/GDP ratio lower than -0.50 (50 percent of GDP). Interestingly, the coefficient on the interaction between this dummy and the NFA variable was positive and significant, although quite small, for developing countries. The coefficient on the NFA variable fell slightly but its statistical significance remained unaffected for the developing country sample. This indicates the possibility of threshold effects in the relationship between NFA stocks and the evolution of current accounts and bears further investigation in future work.

\section{IV.2 Fitted Current Accounts}

We now generate fitted values of current account positions for the countries in our sample using the coefficient estimates from the panel regressions (based on 5-year averages) and compare them with actual current account positions. Figure 3 shows the actual and fitted values of current account to GDP ratios for industrial and developing countries, with the fitted values generated from the respective OLS panel regressions for each of these groups (columns 3 and 4, respectively, in Table 3). The equations have a reasonably good fit by the standards of such cross-country exercises.

The balance of payments identity that we have relied on for much of our analysis implies that current account deficits must be offset by inflows on the capital account. Another 
way of stating this is that, for a country to run a current account deficit, other countries must be willing to contemporaneously finance the deficit by acquiring that country's liabilities. ${ }^{13}$ Over the last three decades, developing countries as a block have generally run net aggregate current account deficits, which are then financed by industrial countries. However, patterns of capital flows from industrial to developing countries have fluctuated quite considerably over time.

In terms of our estimation framework, including an aggregate measure of net capital flows from industrial to developing countries is essentially identical to including time dummies since this variable would be the same for all developing countries in a given time period. However, for the purposes of making out-of-sample statements about the "normal" level of current accounts, given a particular magnitude of capital flows from industrial to developing countries, replacing the time dummies with this variable would facilitate interpretation. An underlying (stylized) presumption here is that, based on factors such as macroeconomic conditions among industrial countries, investors in these countries make a first-stage decision about the size of capital flows to developing countries. These flows are then assumed to be apportioned among developing countries (thereby financing their current account deficits) based on their macroeconomic and structural characteristics. Our approach is more direct than the alternative of including variables such as industrial country GDP growth or interest rates in the estimation, since these variables are at best imperfect proxies for the determinants of net capital flows from industrial to developing countries. Of course, these flows are probably also driven by macroeconomic conditions in the group of developing countries. We recognize this endogeneity but dealing with is not critical for our purposes. ${ }^{14}$

${ }^{13}$ Bosworth and Collins (1998) find that a large proportion of capital inflows into developing countries is indeed used to finance current account deficits. Countries could also finance current account deficits by running down their reserve positions. This approach is likely to be sustainable only for short periods of time. Since our focus is on current account determination at relatively low frequencies, we ignore the role of fluctuations in reserves in our analysis.

${ }^{14}$ The flip side to this endogeneity is the notion that domestic saving could be influenced by capital inflows. Reinhart and Talvi (1998) argue that, in their sample of Asian and Latin American countries, long-run saving behavior has little do with capital inflows and appears instead to be driven by the sorts of structural determinants analyzed in this paper. 
An interesting question at this juncture is how important the potential role of aggregate net capital inflows to developing countries is in generating a good fit for this group of countries. To shed some light on this, we reestimated the panel regression for developing countries after excluding the time dummies. The adjusted Rsquared dropped from 0.44 to 0.36 , indicating the importance of aggregate time effects that influence current account variations across all developing countries.

Next, we examine how well our equation works in replicating a summary measure of the current account across all developing countries. To construct an aggregate developing country measure of the current account, we add up the levels of the current account balances of developing countries and express this as a ratio of the sum of GDPs for this group of countries, with both variables expressed in constant U.S. dollars (and expressed as 5-year averages). Predicted current accounts for each country are then aggregated across all developing countries in a similar manner.

Figure 4 (first panel) shows an aggregate measure of current accounts as a ratio to GDP for developing countries and predicted values for this variable from two OLS regressions-one with and the other without the time dummies. The figure shows that the empirical model analyzed in this paper does a far better job of replicating current account variations for developing countries as a group rather than individually. Further, time effects, which we interpret as capturing net capital flows to developing countries, appear to be quite important for matching the within-sample variation of developing country current accounts. The remaining panels of this table show the results of similar exercises (based on the regression for all developing countries) for countries in Asia, Africa and Latin America, respectively. In all cases, the regression with time effects does a better job of picking up the variation in aggregate current accounts for these areas compared to the regression that excludes time effects. ${ }^{15}$

This exercise has demonstrated that, using coefficient estimates from the panel regressions and based on projections of current account balances for industrial countries, it would be straightforward to generate predicted current account positions for developing

\footnotetext{
${ }^{15}$ The turnaround in the aggregate current account position for Africa between the first and second halves of the 1980s is largely attributable to developments in Nigeria and South Africa.
} 
countries, either individually or for particular blocks. An important feature of these predicted current accounts is that they reflect the effects of medium-term rather than short-term determinants of current account variation and can, therefore, be interpreted as providing some indication of a country's "normal" current account position, conditional on its structural and macroeconomic attributes and based on the historical experiences of a large sample of developing countries. Further, it is relatively easy to incorporate predictions about aggregate net capital flows from industrial to developing countries in making such assessments.

\section{Robustness Tests}

In this section, we consider additional robustness tests for our results. Rather than present a plethora of results for sensitivity tests in different dimensions, here we only summarize the main features of the results.

\section{$V .1$ Fixed Effects}

Many cross-country panel studies use country fixed effects in order to capture all country-specific effects. Our view is that, for understanding cross-country variation in current accounts, including fixed effects would detract from much of the economically meaningful parts of the analysis. Indeed, as shown in Table 1, about 40 percent of the sample variation of the current account to GDP ratio is attributable to cross-section rather than time-series variation, for both the industrial and developing country samples. Thus, using fixed effects estimators would sweep under the rug much of the cross-country variation in current accounts that is, after all, the focus of this study. ${ }^{16}$

Nevertheless, as a robustness check, we redid the estimates including country fixed effects and dropping those regressors that, by construction, have no time variation-terms of trade volatility; average output growth; and the openness indicator. The results are reported in

\footnotetext{
${ }^{16}$ A similar point, in the context of cross-country growth and convergence regressions, is made forcefully by Quah (1996, p. 38) and is echoed by Lane (1998) in his work on the determinants of external debt.
} 
Table $4 .{ }^{17}$ The government budget balance continues to be positively related to the current account balance for the full sample and for developing countries. The coefficients on the NFA to GDP ratio are smaller than the corresponding OLS coefficients, but are still significantly positive except in columns 3 and 5. This weaker result in the FE estimates is not unsurprising since this variable would be expected to be more important for understanding cross-country differences rather than within-country evolutions of current account balances. The youth dependency ratio is still negatively related to current account balances for the developing countries excluding Africa, although the financial deepening variable is no longer significant.

One noteworthy difference between the OLS and FE estimates is that, for the developing countries, the FE specification yields statistically significant coefficients on the relative income and relative income squared terms that are more in line with the stages of development hypothesis. Since the OLS regressions included controls for average output growth, it is possible that the effects of relative income were masked by the systematic differences in growth rates associated with convergence effects. However, when we omitted average output growth from the OLS specifications, the coefficients and associated standard errors on the relative income terms did not change much. Thus, only when we control for country characteristics using FE estimation do we find some evidence that current accounts in developing countries appear consistent with the stages of development hypothesis. ${ }^{18}$

An alternative econometric approach to cross-country panel data, used by some authors such as Alesina, Hausmann, Hommes and Stein (1999), is to estimate an FE model but to then regress the estimated fixed effects on time-invariant country-specific variables in order to understand the determinants of cross-country variations in the dependent variable. Results from

\footnotetext{
${ }^{17}$ The last row of Table 4 reports Hausman test statistics for the validity of random effects (RE) versus fixed effects specifications. For the industrial countries and the full sample of developing countries, we could not reject the null hypothesis that the RE specification is appropriate. We estimated RE models for these two sub-samples but few of the results were affected. Hence, to maintain consistency, we report only FE results in this table.

${ }^{18}$ To check if the East Asian countries in our sample could be driving the OLS and FE coefficients on the relative income terms in columns 4 and 5, we re-estimated the equations excluding them. The coefficient on the squared relative income term fell slightly in both cases but little else changed.
} 
such second-stage regressions using the estimated fixed effects as the dependent variable are reported in Table 5. For this part of the analysis, we tried a number of additional variables used in the growth literature. Few of these variables yielded significant results. Hence, we report estimates using only a couple of additional country-specific variables. Note also that data constraints (related to the availability of data for these additional variables) slightly lower the sample sizes in Table 5 relative to the basic FE estimates.

Consistent with the OLS results, terms of trade volatility is positively associated with current account balances, but this result is not true either for industrial countries or for the developing country sample when African countries are excluded. Among developing countries, higher average GDP growth is positively correlated with current account balances.

Interestingly, the human capital variable used by Hall and Jones (1999) is strongly negatively correlated with current account balances. This is consistent with the notion that the returns to physical capital are likely to be higher in countries with relatively higher stocks of human capital; thus, larger current account deficits in countries with relatively high human capital stocks could reflect investment inflows. We also tried using a variable that captures the price of physical capital relative to that of consumption. Jones (1994) interprets this variable as an indicator of tax and other distortions that influence investment decisions. Among developing countries excluding Africa, a higher relative price of capital is indeed associated with smaller current account deficits, consistent with the notion that investment levels across countries are negatively correlated with the relative price of capital. ${ }^{19}$

Overall, we view the results from FE estimation as supportive of the main conclusions we derived from the basic OLS specifications. Nevertheless, given our interest in explaining low frequency cross-country variations in current account positions with structural variables, the OLS estimator is preferable to the FE estimator for reasons cited earlier.

\footnotetext{
${ }^{19}$ We thank Sergio Rebelo for this suggestion. Jones (1994) finds that the relative price of machinery is more important in cross-country growth regressions than the relative prices of the other components of investment. The relative prices of the components did not in general enter significantly into any of our regressions either independently or once we had controlled for the relative price of total investment.
} 


\section{V.2 Other Econometric Issues}

A possible concern with our baseline estimates is the effect of serial correlation. Although the standard errors for the coefficient estimates are robust to serial correlation (and heteroscedasticity), the coefficient estimates could themselves be contaminated by the presence of serial correlation. Since we use 5-year averaged data in the estimation, however, it is less likely that serial correlation is a problem. When we included the lagged (5-year average) level of the current account in the panel regressions, the coefficient on this variable was generally not economically or statistically significant and, in any case, did not have much effect on the point estimates of the other coefficients. More sophisticated attempts to identify and deal with serial correlation also did not make much difference.

Although we have been cautious about not assigning causal explanations to the conditional correlations that we have found, the issue of endogeneity in our specifications is another potential concern. Some of the right hand side variables in our specifications, such as government budget balances, could be influenced by current account developments. Further, in a dynamic context, there is clearly a relationship between current accounts and the stock of NFAs. However, we faced two major problems with IV estimation. First, the lack of additional variables that could constitute good instruments. In addition, the low correlations between lagged and contemporaneous values of relevant variables such as the government budget balance to GDP ratio meant that lagged values of the right hand side variables made for poor instruments. Second, given our use of 5-year averages, the sample size shrank considerably when we used lagged values of right hand side variables as instruments. Nevertheless, we experimented with using a set of instruments that included plausibly exogenous variables.

For instance, as instruments for the government budget balance and initial NFA, we used lagged values of these variables, contemporaneous values of all other independent variables (which we take to be exogenous), and lagged values of the time-varying exogenous variables. Numerous combinations of instruments were tried. In general, the coefficients on the instrumented variables were slightly smaller in absolute magnitude in the IV regressions compared with the OLS estimates. However, the standard errors on some of the coefficient estimates increased, reflecting the problems with IV estimation discussed above. Overall, these results were broadly supportive of the conclusions obtained from the OLS estimates. 


\section{V.3 Foreign Aid and the Current Account}

An interesting question that is related to the discussion of causality is that of exogenous variations in the current accounts of developing countries that are attributable to aid and other transfers from abroad. This could give rise to spurious correlations in our data among current account balances and macroeconomic variables. One transparent way to deal with this issue is to include aid and other official grants (expressed as a ratio to GDP) as an additional control. We re-estimated the OLS and FE specifications for developing countries including this variable as a regressor. Table A1 shows that the coefficient on this variable is significantly negative in

the OLS specification for all developing countries. This is the expected result, since inflows of aid should in principle allow a country to finance larger current account deficits. The estimated coefficients on this variable in the other columns of this table are, however, not significant. The coefficients on other variables, in particular the government budget balance and the NFA/GDP ratio, are not much affected when the aid variable is added to the regressions. The one major difference, however, is that the coefficients on the relative income terms are no longer significant in the FE regressions.

\section{V.4 Regressions with Annual Data}

Finally, in order to examine the robustness of the results at higher frequencies, we reestimated the panel regressions using annual data rather than 5-year averages. As noted earlier, we were concerned that there could be considerable noise and measurement error in annual data for some of the developing countries. Nevertheless, it is useful to examine the sensitivity of the results to the choice of data frequency.

Using the annual data, we re-estimated the baseline OLS specifications with time effects and also included lagged values of the current account to GDP ratio and, in order to capture relative price effects, lagged changes of (the logarithms of) the real effective exchange rate. The results are reported in Table A2. The coefficients on the lagged current account to GDP ratio are in the range of 0.50-0.60 for both the industrial and developing country samples, indicating rather limited persistence in this variable even at an annual frequency. The estimated 
relative price effects on current accounts are negative, as would be expected, but are statistically significant only for industrial countries. ${ }^{20}$

For developing countries, government budget balances remain positively associated with current account balances even at annual frequencies. Financial deepening and terms of trade volatility are also positively associated with current accounts among developing countries. The coefficients on many of the other variables have the same sign and often similar magnitudes as in the regressions using the 5-year averaged data, but they are much less precisely estimated. This could in part be due to the greater amount of noise in annual data for developing countries but probably also reflects the fact that variables such as relative dependency ratios are far more important for explaining medium-term rather than short-term variations in current account balances.

\section{Concluding Remarks}

We conclude by summarizing some of the main results from the paper, followed by a brief discussion of directions for further research. The aim of this paper was to investigate the empirical relationships between current account balances and variables that, through their effects on saving and investment, would be expected to influence medium-term variation in saving-investment balances and, hence, in the current account. We used a broad sample of industrial and developing countries and employed cross-section and panel regressions to investigate these relationships across countries and over time. The main results were subjected to an extensive battery of robustness tests to ensure that they were not sensitive to issues such as choice of empirical specification and frequency of the data. We found a few similarities and some interesting differences among different groups of countries that we examined.

We found that government budget balances, initial net foreign asset positions and, for developing countries, indicators of financial deepening are positively correlated with current

\footnotetext{
${ }^{20}$ These results are not that surprising since one would expect relative price effects to be more systematically related to variations in the trade balance rather than the current account. When we included the contemporaneous rather than lagged change in the real exchange rate in the regressions and instrumented this variable with its lags, the coefficients were negative and slightly larger, but were still not statistically significant.
} 
account balances. Among developing countries, we also found that higher terms of trade volatility is associated with larger current account surpluses (or smaller deficits), perhaps because greater macroeconomic uncertainty increases domestic saving and possibly also has a negative impact on investment. The degree of openness to international trade appears to be weakly associated with larger current account deficits among developing countries. We found at best limited evidence to support the patterns of evolutions in current accounts predicted by the stages-of-development hypothesis. Other potentially important variables such as indicators of capital controls and average GDP growth, however, appear to bear little systematic relationship with current account balances.

The stylized facts presented in this paper have left a number of important questions unanswered, presenting a fertile agenda for future work. For instance, from an intertemporal perspective, a better understanding of the dynamic effects on the current account of shocks with different degrees of persistence could have important theoretical as well as policy implications. Another important issue is to separate out the channels, i.e., via the trade balance or other components of the current account, through which different shocks could affect variations in the current account. The empirical regularities documented in this paper point to some interesting directions for further work towards understanding the factors that ultimately determine sustainable current account balances in the medium term. 


\section{Data Appendix}

The data used in this paper were drawn from a number of different sources. We provide below a listing of the mnemonics for the variables used in the analysis, descriptions of these variables and the source(s) from which the primary data for constructing these variables were taken. A listing of the countries in the final sample, along with the country groupings used in the analysis, is also provided below. For most countries, data were available from 1971 through 1995.

\begin{tabular}{|c|c|c|}
\hline Mnemonic & Source* & Variable description \\
\hline CAGDP & IFS & Current account to GDP ratio \\
\hline GOVBGDP & WBSD & General government budget balance, ratio to GDP \\
\hline NFAGDP & LM, Sinn & Stock of net foreign assets, ratio to GDP \\
\hline RELY & WBSD & $\begin{array}{l}\text { Relative per capita income, adjusted by PPP exchange rates } \\
\text { Measured relative to the U.S., range ( } 0 \text { to } 1]\end{array}$ \\
\hline RELDEPY & WBSD & $\begin{array}{l}\text { Youth dependency ratio (relative to mean across all countries) } \\
\text { Population under } 15 \text { / Population between } 15 \text { and } 65\end{array}$ \\
\hline RELDEPO & WBSD & $\begin{array}{l}\text { Old dependency ratio (relative to mean across all countries) } \\
\text { Population over } 65 \text { / Population between } 15 \text { and } 65\end{array}$ \\
\hline YGRAVG & WBSD & Average real GDP growth \\
\hline YGRSD & WBSD & Standard deviation of GDP growth \\
\hline TOTSD & WDI, IMF & Standard deviation of terms of trade \\
\hline LREER & IFS, IMF & Logarithm of trade-weighted real exchange rate \\
\hline OPEN & IFS & $\begin{array}{l}\text { Openness indicator: ratio of exports plus imports of goods and } \\
\text { nonfactor services to GDP }\end{array}$ \\
\hline FDEEP & IFS & Financial deepening, ratio of M2 to GDP \\
\hline $\mathrm{KC} 2$ & GM & Capital controls on current account transactions \\
\hline $\mathrm{KC} 3$ & GM & Capital controls on capital account transactions \\
\hline
\end{tabular}

* These are sources for basic data used to construct the corresponding variables. WBSD: World Bank Saving Database (see Loayza et al., 1998, for a description); WDI: World Development Indicators; IFS: IMF's International Financial Statistics; IMF: Other IMF databases; Sinn: Stefan Sinn (1990); GM: Gian Maria Milesi-Ferretti (1998); LM: Philip Lane and Gian Maria Milesi-Ferretti (1999).

We attempted to minimize the amount of preliminary screens on the data, choosing instead to check the sensitivity of each of our main results to the presence and effects of outliers. These are noted in the text of the paper. However, to maintain consistency in the set of countries used for the cross-section and panel analyses, we dropped those countries for which we had fewer than 10 full observations. We also dropped two countries-Kuwait and Nicaragua - that had average current account to GDP ratios considerably out of line with other countries in the sample. The final sample includes 18 industrial and 71 developing countries. 


\section{Industrial Countries}

Australia (AUS), Austria (AUT), Canada (CAN), Denmark (DNK), Finland (FIN), France (FRA), Greece (GRC), Iceland (ISL), Ireland (IRL), Italy (ITA), Japan (JPN), Netherlands (NLD), New Zealand (NZL), Norway (NOR), Portugal (PRT), Spain (ESP), Switzerland (CHE), United States (USA).

\section{Developing countries}

Algeria (DZA), Argentina (ARG), Bahrain (BHR), Bangladesh (BGD), Benin (BEN), Bolivia (BOL), Botswana (BWA), Brazil (BRA), Burkina Faso (BFA), Burundi (BDI), Cameroon (CMR), Chad (TCD), Chile (CHL), Colombia (COL), Congo (COG), Costa Rica (CRI), Cote d'Ivoire (CIV), Dominica (DMA), Ecuador (ECU), Egypt (EGY), El Salvador (SLV), Gabon (GAB), Gambia (GMB), Ghana (GHA), Guatemala (GTM), Haiti (HTI), Honduras (HND), India (IND), Indonesia (IDN), Iran (IRN), Israel (ISR), Jamaica (JAM), Jordan (JOR), Kenya (KEN), Korea (KOR), Madagascar (MDG), Malawi (MWI), Malaysia (MYS), Mali (MLI), Mauritania (MRT), Mauritius (MUS), Mexico (MEX), Morocco (MAR), Nepal (NPL), Niger (NER), Nigeria (NGA), Pakistan (PAK), Panama (PAN), Papua New Guinea (PNG), Paraguay (PRY), Peru (PER), Philippines (PHL), Rwanda (RWA), Senegal (SEN), Seychelles (SYC), Sierra Leone (SLE), Singapore (SGP), South Africa (ZAF), Sri Lanka (LKA), Swaziland (SWZ), Syria (SYR), Thailand (THA), Togo (TGO), Trinidad \& Tobago (TTO), Tunisia (TUN), Turkey (TUR), Uganda (UGA), Uruguay (URY), Venezuela (VEN), Zambia (ZMB), Zimbabwe (ZWE). 


\section{References}

Aizenman, Joshua, 1994, "Monetary and Real Shocks, Productive Capacity and Exchange Rate Regimes," Economica, vol. 61, pp. 407-434.

Alesina, Alberto, Ricardo Hausmann, Rudolf Hommes, and Ernesto Stein, 1999, "Budget Institutions and Fiscal Performance in Latin America," Journal of Development Economics, vol. 59, pp. 253-273.

Bosworth, Barry, and Susan M. Collins, 1999, "Capital Flows to Developing Economies: Implications for Saving and Investment," Brookings Papers on Economic Activity, pp.143-180.

Calderon, Cesar, Alberto Chong, and Norman Loayza, 1999, "Determinants of Current Accounts in Developing Countries," Manuscript, The World Bank.

Debelle, Guy, and Hamid Faruqee, 1996, "What Determines the Current Account ? A CrossSectional and Panel Approach," IMF Working Paper 96/58.

Ghosh, Atish R., 1995, “International Capital Mobility Amongst the Major Industrialized Countries: Too Little or Too Much?” Economic Journal, vol. 105, pp. 107-128.

Ghosh, Atish R., and Jonathan D. Ostry, 1995, “The Current Account in Developing Countries: A Perspective from the Consumption-Smoothing Approach," World Bank Economic Review, vol. 9, pp. 305-333.

Edwards, Sebastian, 1995, "Why are Saving Rates So Different Across Countries? An International Comparative Analysis,” NBER Working Paper No. 5097.

Glick, Reuven, and Kenneth Rogoff, 1995, "Global versus Country-Specific Productivity Shocks and the Current Account," Journal of Monetary Economics, pp. 159-192.

Hall, Robert E., and Charles I. Jones, 1999, "Why Do Some Countries Produce So Much More Output Per Worker than Others “ Quarterly Journal of Economics, vol. 114, pp. 83-116.

Isard, Peter, and Hamid Faruqee, 1998, eds., "Exchange Rate Assessment: Extensions of the Macroeconomic Balance Approach,” IMF Occasional Paper No. 167.

Jones, Charles I., 1994, "Economic Growth and the Relative Price of Capital," Journal of Monetary Economics, vol. 34, pp. 359-382.

Kraay, Aart, and Jaume Ventura, 2000, "Current Accounts in Debtor and Creditor Countries," Quarterly Journal of Economics, forthcoming. 
Lane, Philip, 1998, “Empirical Perspectives on Long-Term External Debt,” Manuscript, Trinity College, Dublin.

Lane, Philip, and Gian Maria Milesi-Ferretti, 1999, "The External Wealth of Nations: Measures of Foreign Assets and Liabilities for Industrial and Developing Countries," IMF Working Paper 99/115.

Lee, Jaewoo, and Menzie Chinn, 1998, "The Current Account and the Real Exchange Rate: A Structural VAR Analysis of Major Currencies,” NBER Working Paper No. 6495.

Loayza, Norman, Humberto Lopez, Klaus Schmidt-Hebbel, and Luis Serven, 1998, "The World Saving Database," Manuscript, The World Bank.

Masson, Paul, Tamim Bayoumi, and Hossein Samiei, 1998, "International Evidence on the Determinants of Private Saving,” World Bank Economic Review, vol. 12, pp. 483-501.

Milesi-Ferretti, Gian Maria, 1998, "Why Capital Controls? Theory and Evidence," in S. Eijffinger and H. Huizinga, eds., Positive Political Economy: Theory and Evidence (Cambridge University Press).

Nason, James, and John H. Rogers, 1999, "Investment and the Current Account in the Short Run and the Long Run," International Finance Discussion Paper 647, Board of Governors of the Federal Reserve.

Obstfeld, Maurice, and Kenneth Rogoff, 1998, Foundations of International Macroeconomics (Cambridge, MA: MIT Press).

Prasad, Eswar S., 1999, "International Trade and the Business Cycle," Economic Journal, vol. 109, pp. 588-607.

Quah, Danny T., 1996, “Convergence Empirics Across Economies with (Some) Capital Mobility," Journal of Economic Growth, vol. 1, pp. 95-124.

Razin, Assaf, 1995, "The Dynamic-Optimizing Approach to the Current Account: Theory and Evidence," in Understanding Interdependence: The Macroeconomics of the Open Economy, Peter Kenen ed. (Princeton, New Jersey: Princeton University Press).

Reinhart, Carmen M., and Ernesto Talvi, 1998, "Capital Flows and Saving in Latin America and Asia: A Reinterpretation," Journal of Development Economics, vol. 57, pp. 45-66.

Roldos, Jorge, 1996, "Human Capital, Borrowing Constraints, and the Stages of the Balance of Payments," Manuscript, IMF. 
Schmidt-Hebbel, Klaus, Steven B. Webb, and Giancarlo Corsetti, 1992, "Household Saving in Developing Countries: First Cross-Country Evidence," World Bank Economic Review, vol. 6, pp. 529-547.

Serven, Luis, 1998, "Macroeconomic Uncertainty and Private Investment in LDCs: An Empirical Investigation," manuscript, World Bank.

Sinn, Stefan, 1990, "Net External Asset Positions of 145 Countries,” Kieler Studien 234, Kiel University. 
Table 1. Decomposition of Variance into Cross Section and Time Series Components

(in percent)

\begin{tabular}{|c|c|c|c|c|}
\hline & \multicolumn{2}{|c|}{ Industrial Countries } & \multicolumn{2}{|c|}{ Developing Countries } \\
\hline & Across countries & Over time & Across countries & Over time \\
\hline \multicolumn{5}{|l|}{ Current account } \\
\hline to GDP ratio & 39.05 & 60.95 & 43.56 & 56.44 \\
\hline \multicolumn{5}{|l|}{ Govt. budget balance } \\
\hline to GDP ratio & 41.31 & 58.69 & 46.94 & 53.06 \\
\hline NFA to GDP ratio & 80.07 & 19.93 & 67.37 & 32.63 \\
\hline Relative income & 93.21 & 6.79 & 90.92 & 9.08 \\
\hline Relative income squared & 92.43 & 7.57 & 76.88 & 23.12 \\
\hline Relative dependency ratio (young) & 61.59 & 38.41 & 88.82 & 11.18 \\
\hline Relative dependency ratio (old) & 75.22 & 24.78 & 94.26 & 5.74 \\
\hline Financial deepening & 83.36 & 16.64 & 84.36 & 15.64 \\
\hline Terms of trade volatility & 23.49 & 76.51 & 35.69 & 64.31 \\
\hline GDP growth & 9.07 & 90.93 & 9.91 & 90.09 \\
\hline Openness ratio & 85.58 & 14.42 & 90.78 & 9.22 \\
\hline Capital controls (current account) & 64.83 & 35.17 & 60.95 & 39.05 \\
\hline Capital controls (capital account) & 50.25 & 49.75 & 70.43 & 29.57 \\
\hline
\end{tabular}

Notes: This table shows the proportion of the total variance (of 5-year nonoverlapping averages) of each variable that is attributable to variation across countries and over time, respectively. For four of the variables--NFA to GDP ratio; terms of trade volatility; GDP growth; and the openness ratio--the variance decomposition is for the underlying ( 5 year averaged) data, rather than the transformations that are used in the regressions (e.g. average GDP growth over the full sample). 
Table 2. Cross Section Regressions

(Dependent Variable --Current Account to GDP Ratio)

\begin{tabular}{|c|c|c|c|c|c|}
\hline & Full Sample & $\begin{array}{c}\text { Full Sample } \\
\text { Excluding } \\
\text { Africa }\end{array}$ & $\begin{array}{l}\text { Industrial } \\
\text { Countries } \\
\end{array}$ & $\begin{array}{c}\text { Developing } \\
\text { Countries } \\
\end{array}$ & $\begin{array}{c}\text { Developing } \\
\text { Countries } \\
\text { Excluding } \\
\text { Africa } \\
\end{array}$ \\
\hline $\begin{array}{l}\text { Govt. budget balance } \\
\text { (ratio to GDP) }\end{array}$ & $\begin{array}{l}0.375^{* * *} \\
(0.120)\end{array}$ & $\begin{array}{l}0.153^{* *} \\
(0.068)\end{array}$ & $\begin{array}{l}0.340^{* * *} \\
(0.078)\end{array}$ & $\begin{array}{l}0.458 * * * \\
(0.146)\end{array}$ & $\begin{array}{l}0.246 * * \\
(0.103)\end{array}$ \\
\hline NFA to GDP ratio & $\begin{array}{l}0.046^{* *} \\
(0.023)\end{array}$ & $\begin{array}{l}0.051 * * * \\
(0.016)\end{array}$ & $\begin{array}{l}0.127^{* * *} \\
(0.023)\end{array}$ & $\begin{array}{c}0.038 \\
(0.026)\end{array}$ & $\begin{array}{r}0.024 \\
(0.027)\end{array}$ \\
\hline Relative income & $\begin{array}{l}0.119 * * \\
(0.056)\end{array}$ & $\begin{array}{l}0.097 * * * \\
(0.036)\end{array}$ & $\begin{array}{l}0.174^{*} \\
(0.085)\end{array}$ & $\begin{array}{c}0.013 \\
(0.106)\end{array}$ & $\begin{array}{r}0.046 \\
(0.055)\end{array}$ \\
\hline $\begin{array}{l}\text { Relative income } \\
\text { squared }\end{array}$ & $\begin{array}{l}-0.096^{* *} \\
(0.039)\end{array}$ & $\begin{array}{l}0.070^{* *} \\
(0.031)\end{array}$ & $\begin{array}{l}-0.176^{*} \\
(0.072)\end{array}$ & $\begin{array}{c}0.117 \\
(0.150)\end{array}$ & $\begin{array}{r}0.042 \\
(0.086)\end{array}$ \\
\hline $\begin{array}{l}\text { Relative dependency ratio } \\
\text { (young) }\end{array}$ & $\begin{array}{l}-0.054 * \\
(0.031)\end{array}$ & $\begin{array}{l}-0.029 \\
(0.027)\end{array}$ & $\begin{array}{l}-0.057 \\
(0.060)\end{array}$ & $\begin{array}{l}-0.060^{*} \\
(0.035)\end{array}$ & $\begin{array}{l}-0.057 \\
(0.040)\end{array}$ \\
\hline $\begin{array}{l}\text { Relative dependency ratio } \\
\text { (old) }\end{array}$ & $\begin{array}{c}-0.173 \\
(0.138)\end{array}$ & $\begin{array}{r}-0.097 \\
(0.107)\end{array}$ & $\begin{array}{r}0.195 \\
(0.124)\end{array}$ & $\begin{array}{l}-0.156 \\
(0.195)\end{array}$ & $\begin{array}{l}-0.211 \\
(0.174)\end{array}$ \\
\hline $\begin{array}{l}\text { Financial deepening } \\
\text { (M2/GDP) }\end{array}$ & $\begin{array}{l}0.031 * * \\
(0.011)\end{array}$ & $\begin{array}{c}0.023^{*} \\
(0.012)\end{array}$ & $\begin{array}{r}0.001 \\
(0.014)\end{array}$ & $\begin{array}{l}0.045^{* *} \\
(0.018)\end{array}$ & $\begin{array}{c}0.044^{*} \\
(0.023)\end{array}$ \\
\hline $\begin{array}{l}\text { Terms of trade } \\
\text { volatility }\end{array}$ & $\begin{array}{r}0.022 \\
(0.028)\end{array}$ & $\begin{array}{l}0.053 * * \\
(0.021)\end{array}$ & $\begin{array}{l}-0.092^{* *} \\
(0.034)\end{array}$ & $\begin{array}{r}0.027 \\
(0.028)\end{array}$ & $\begin{array}{l}0.052 * * \\
(0.026)\end{array}$ \\
\hline Average GDP growth & $\begin{array}{c}-0.152 \\
(0.184)\end{array}$ & $\begin{array}{c}-0.099 \\
(0.169)\end{array}$ & $\begin{array}{l}2.409^{* * *} \\
(0.364)\end{array}$ & $\begin{array}{l}-0.184 \\
(0.185)\end{array}$ & $\begin{array}{l}-0.180 \\
(0.168)\end{array}$ \\
\hline Openness ratio & $\begin{array}{r}-0.010 \\
(0.008)\end{array}$ & $\begin{array}{r}0.006 \\
(0.008)\end{array}$ & $\begin{array}{l}-0.040 \\
(0.030)\end{array}$ & $\begin{array}{l}-0.024 * * \\
(0.012)\end{array}$ & $\begin{array}{l}-0.017 \\
(0.015)\end{array}$ \\
\hline $\begin{array}{l}\text { Capital controls } \\
\text { (current account) }\end{array}$ & $\begin{array}{c}0.011 \\
(0.011)\end{array}$ & $\begin{array}{r}0.006 \\
(0.008)\end{array}$ & $\begin{array}{l}0.016^{* *} \\
(0.006)\end{array}$ & $\begin{array}{r}0.010 \\
(0.014)\end{array}$ & $\begin{array}{r}0.005 \\
(0.011)\end{array}$ \\
\hline $\begin{array}{l}\text { Capital controls } \\
\text { (capital account) }\end{array}$ & $\begin{array}{c}0.001 \\
(0.012)\end{array}$ & $\begin{array}{l}-0.002 \\
(0.008)\end{array}$ & $\begin{array}{l}-0.027 \\
(0.010)\end{array}$ & $\begin{array}{l}-0.005 \\
(0.017)\end{array}$ & $\begin{array}{l}-0.008 \\
(0.013)\end{array}$ \\
\hline $\begin{array}{l}\text { Dummy for oil- } \\
\text { exporting countries }\end{array}$ & $\begin{array}{l}0.023^{* * *} \\
(0.008)\end{array}$ & $\begin{array}{l}0.023 * * * \\
(0.006)\end{array}$ & $\begin{array}{l}\cdots \\
\cdots\end{array}$ & $\begin{array}{c}0.017 * \\
(0.009)\end{array}$ & $\begin{array}{l}0.016^{* *} \\
(0.013)\end{array}$ \\
\hline Adjusted Rsquared & 0.51 & 0.64 & 0.94 & 0.46 & 0.57 \\
\hline Number of observations & 89 & 56 & 18 & 71 & 48 \\
\hline
\end{tabular}

Notes: The dependent and independent variables are the full sample averages of the corresponding annual variables for each country. Robust standard errors are reported in parentheses. The symbols *, **, and *** indicate statistical significance at the 10 percent, 5 percent, and 1 percent levels, respectively. 
Table 3. Panel Regressions, OLS Specification with Time Effects

(Dependent Variable -- Current Account to GDP Ratio)

\begin{tabular}{|c|c|c|c|c|c|}
\hline & Full Sample & $\begin{array}{c}\text { Full Sample } \\
\text { Excluding } \\
\text { Africa }\end{array}$ & $\begin{array}{l}\text { Industrial } \\
\text { Countries }\end{array}$ & $\begin{array}{c}\text { Developing } \\
\text { Countries } \\
\end{array}$ & $\begin{array}{c}\text { Developing } \\
\text { Countries } \\
\text { Excluding } \\
\text { Africa } \\
\end{array}$ \\
\hline $\begin{array}{l}\text { Govt. budget balance } \\
\text { (ratio to GDP) }\end{array}$ & $\begin{array}{l}0.306 * * * \\
(0.065)\end{array}$ & $\begin{array}{l}0.195 * * * \\
(0.059)\end{array}$ & $\begin{array}{c}0.131 \\
(0.079)\end{array}$ & $\begin{array}{l}0.389 * * * \\
(0.071)\end{array}$ & $\begin{array}{l}0.259 * * * \\
(0.062)\end{array}$ \\
\hline NFA to GDP ratio & $\begin{array}{l}0.048 * * * \\
(0.012)\end{array}$ & $\begin{array}{l}0.047 * * * \\
(0.015)\end{array}$ & $\begin{array}{l}0.074 * * * \\
(0.016)\end{array}$ & $\begin{array}{l}0.043 * * * \\
(0.011)\end{array}$ & $\begin{array}{l}0.039 * * * \\
(0.013)\end{array}$ \\
\hline Relative income & $\begin{array}{c}0.042 \\
(0.037)\end{array}$ & $\begin{array}{c}0.041 \\
(0.034)\end{array}$ & $\begin{array}{l}-0.038 \\
(0.096)\end{array}$ & $\begin{array}{l}-0.088 \\
(0.063)\end{array}$ & $\begin{array}{l}-0.103 \\
(0.066)\end{array}$ \\
\hline $\begin{array}{l}\text { Relative income } \\
\text { squared }\end{array}$ & $\begin{array}{l}-0.018 \\
(0.034)\end{array}$ & $\begin{array}{l}-0.013 \\
(0.032)\end{array}$ & $\begin{array}{c}0.031 \\
(0.075)\end{array}$ & $\begin{array}{l}0.250 * * \\
(0.098)\end{array}$ & $\begin{array}{l}0.268 * * \\
(0.107)\end{array}$ \\
\hline $\begin{array}{l}\text { Relative dependency ratio } \\
\text { (young) }\end{array}$ & $\begin{array}{l}-0.025 \\
(0.024)\end{array}$ & $\begin{array}{l}-0.023 \\
(0.018)\end{array}$ & $\begin{array}{l}-0.108 * \\
(0.063)\end{array}$ & $\begin{array}{l}-0.039 \\
(0.032)\end{array}$ & $\begin{array}{l}-0.055^{*} \\
(0.030)\end{array}$ \\
\hline $\begin{array}{l}\text { Relative dependency ratio } \\
\text { (old) }\end{array}$ & $\begin{array}{l}-0.051 \\
(0.086)\end{array}$ & $\begin{array}{l}-0.010 \\
(0.082)\end{array}$ & $\begin{array}{l}-0.109 \\
(0.120)\end{array}$ & $\begin{array}{l}-0.138 \\
(0.156)\end{array}$ & $\begin{array}{l}-0.156 \\
(0.169)\end{array}$ \\
\hline Financial deepening & $\begin{array}{l}0.026 * * \\
(0.008)\end{array}$ & $\begin{array}{l}0.020 * * \\
(0.008)\end{array}$ & $\begin{array}{c}0.018 \\
(0.013)\end{array}$ & $\begin{array}{l}0.039 * * * \\
(0.013)\end{array}$ & $\begin{array}{l}0.037 * * \\
(0.017)\end{array}$ \\
\hline $\begin{array}{l}\text { Terms of trade } \\
\text { volatility }\end{array}$ & $\begin{array}{c}0.018 \\
(0.022)\end{array}$ & $\begin{array}{l}0.044 * * \\
(0.020)\end{array}$ & $\begin{array}{c}0.007 \\
(0.057)\end{array}$ & $\begin{array}{c}0.022 \\
(0.021)\end{array}$ & $\begin{array}{l}0.034^{*} \\
(0.022)\end{array}$ \\
\hline Average GDP growth & $\begin{array}{l}-0.052 \\
(0.151)\end{array}$ & $\begin{array}{c}0.020 \\
(0.143)\end{array}$ & $\begin{array}{c}0.727 \\
(0.512)\end{array}$ & $\begin{array}{l}-0.071 \\
(0.157)\end{array}$ & $\begin{array}{l}-0.087 \\
(0.154)\end{array}$ \\
\hline Openness ratio & $\begin{array}{l}-0.008 \\
(0.010)\end{array}$ & $\begin{array}{c}0.001 \\
(0.011)\end{array}$ & $\begin{array}{c}0.023 \\
(0.018)\end{array}$ & $\begin{array}{l}-0.027 * * \\
(0.012)\end{array}$ & $\begin{array}{l}-0.024 \\
(0.015)\end{array}$ \\
\hline $\begin{array}{l}\text { Capital controls } \\
\text { (current account) }\end{array}$ & $\begin{array}{l}0.010 \\
(0.006)\end{array}$ & $\begin{array}{l}0.010 \\
(0.006)\end{array}$ & $\begin{array}{l}0.002 \\
(0.009)\end{array}$ & $\begin{array}{l}0.010 \\
(0.008)\end{array}$ & $\begin{array}{l}0.011 \\
(0.007)\end{array}$ \\
\hline $\begin{array}{l}\text { Capital controls } \\
\text { (capital account) }\end{array}$ & $\begin{array}{l}0.001 \\
(0.007)\end{array}$ & $\begin{array}{l}-0.002 \\
(0.006)\end{array}$ & $\begin{array}{l}0.004 \\
(0.007)\end{array}$ & $\begin{array}{l}-0.004 \\
(0.011)\end{array}$ & $\begin{array}{l}-0.011 \\
(0.012)\end{array}$ \\
\hline $\begin{array}{l}\text { Dummy for oil- } \\
\text { exporting countries }\end{array}$ & $\begin{array}{l}0.020 * * \\
(0.010)\end{array}$ & $\begin{array}{l}0.020 * * \\
(0.008)\end{array}$ & $\begin{array}{l}\cdots \\
\cdots\end{array}$ & $\begin{array}{c}0.012 \\
(0.010)\end{array}$ & $\begin{array}{c}0.011 \\
(0.010)\end{array}$ \\
\hline $\begin{array}{l}\text { Significant time } \\
\text { dummies }\end{array}$ & $86-90$ & $86-90$ & $91-95$ & $81-85$ & $81-85$ \\
\hline Adjusted Rsquared & 0.42 & $\begin{array}{l}0.43 \\
237\end{array}$ & $\begin{array}{l}0.58 \\
82\end{array}$ & 0.44 & $\begin{array}{l}0.45 \\
155\end{array}$ \\
\hline
\end{tabular}

Notes: The dependent and independent variables are non-overlapping 5-year averages of the corresponding annual variables. Robust standard errors are reported in parentheses. The symbols *,**, and $* * *$ indicate statistical significance at the 10 percent, 5 percent, and 1 percent levels, respectively. 
Table 4. Panel Regressions, Fixed Effects Specification with Time Effects (Dependent Variable -- Current Account to GDP Ratio)

\begin{tabular}{|c|c|c|c|c|c|}
\hline & Full Sample & $\begin{array}{c}\text { Full Sample } \\
\text { Excluding } \\
\text { Africa } \\
\end{array}$ & $\begin{array}{l}\text { Industrial } \\
\text { Countries }\end{array}$ & $\begin{array}{c}\text { Developing } \\
\text { Countries }\end{array}$ & $\begin{array}{c}\text { Developing } \\
\text { Countries } \\
\text { Excluding } \\
\text { Africa }\end{array}$ \\
\hline $\begin{array}{l}\text { Govt. budget balance } \\
\text { (ratio to GDP) }\end{array}$ & $\begin{array}{l}0.376 * * * \\
(0.076)\end{array}$ & $\begin{array}{l}0.187 * * \\
(0.076)\end{array}$ & $\begin{array}{c}0.141 \\
(0.113)\end{array}$ & $\begin{array}{l}0.446 * * * \\
(0.096)\end{array}$ & $\begin{array}{l}0.209 * * \\
(0.098)\end{array}$ \\
\hline NFA to GDP ratio & $\begin{array}{l}0.018 * * * \\
(0.008)\end{array}$ & $\begin{array}{l}0.016^{* *} \\
(0.007)\end{array}$ & $\begin{array}{c}0.015 \\
(0.033)\end{array}$ & $\begin{array}{c}0.017 * \\
(0.009)\end{array}$ & $\begin{array}{c}0.012 \\
(0.009)\end{array}$ \\
\hline Relative income & $\begin{array}{l}-0.137 \\
(0.144)\end{array}$ & $\begin{array}{l}-0.122 \\
(0.133)\end{array}$ & $\begin{array}{l}0.859 * * \\
(0.434)\end{array}$ & $\begin{array}{l}-0.322 * \\
(0.186)\end{array}$ & $\begin{array}{l}-0.441 * * \\
(0.171)\end{array}$ \\
\hline $\begin{array}{l}\text { Relative income } \\
\text { squared }\end{array}$ & $\begin{array}{l}0.237 * \\
(0.132)\end{array}$ & $\begin{array}{l}0.256^{* *} \\
(0.121)\end{array}$ & $\begin{array}{l}-0.511^{*} \\
(0.299)\end{array}$ & $\begin{array}{l}0.478 * * \\
(0.193)\end{array}$ & $\begin{array}{l}0.624 * * * \\
(0.176)\end{array}$ \\
\hline $\begin{array}{l}\text { Relative dependency ratio } \\
\text { (young) }\end{array}$ & $\begin{array}{l}-0.053 \\
(0.064)\end{array}$ & $\begin{array}{l}-0.151 * * \\
(0.063)\end{array}$ & $\begin{array}{l}-0.004 \\
(0.102)\end{array}$ & $\begin{array}{l}-0.089 \\
(0.073)\end{array}$ & $\begin{array}{l}-0.196^{* * *} \\
(0.072)\end{array}$ \\
\hline $\begin{array}{l}\text { Relative dependency ratio } \\
\text { (old) }\end{array}$ & $\begin{array}{l}-0.063 \\
(0.335)\end{array}$ & $\begin{array}{l}0.199 \\
(0.307)\end{array}$ & $\begin{array}{l}-0.261 \\
(0.256)\end{array}$ & $\begin{array}{c}0.579 \\
(0.627)\end{array}$ & $\begin{array}{l}1.758^{* *} \\
(0.614)\end{array}$ \\
\hline Financial deepening & $\begin{array}{l}-0.017 \\
(0.025)\end{array}$ & $\begin{array}{l}-0.001 \\
(0.024)\end{array}$ & $\begin{array}{c}0.030 \\
(0.024)\end{array}$ & $\begin{array}{l}-0.039 \\
(0.036)\end{array}$ & $\begin{array}{l}-0.025 \\
(0.037)\end{array}$ \\
\hline $\begin{array}{l}\text { Terms of trade } \\
\text { volatility }\end{array}$ & $\begin{array}{l}\cdots \\
\cdots\end{array}$ & $\begin{array}{l}\cdots \\
\cdots\end{array}$ & $\begin{array}{l}\cdots \\
\cdots\end{array}$ & $\begin{array}{l}\cdots \\
\cdots\end{array}$ & $\begin{array}{l}\cdots \\
\cdots\end{array}$ \\
\hline Average GDP growth & $\begin{array}{l}\cdots \\
\cdots\end{array}$ & $\begin{array}{l}\cdots \\
\cdots\end{array}$ & $\begin{array}{l}\cdots \\
\cdots\end{array}$ & $\begin{array}{l}\cdots \\
\cdots\end{array}$ & $\begin{array}{l}\cdots \\
\cdots\end{array}$ \\
\hline Openness ratio & $\begin{array}{l}\cdots \\
\cdots\end{array}$ & $\begin{array}{l}\cdots \\
\cdots\end{array}$ & $\begin{array}{l}\cdots \\
\cdots\end{array}$ & $\begin{array}{l}\cdots \\
\cdots\end{array}$ & $\begin{array}{l}\cdots \\
\cdots\end{array}$ \\
\hline $\begin{array}{l}\text { Capital controls } \\
\quad \text { (current account) }\end{array}$ & $\begin{array}{c}0.006 \\
(0.010)\end{array}$ & $\begin{array}{l}0.005 \\
(0.010)\end{array}$ & $\begin{array}{l}-0.012 \\
(0.016)\end{array}$ & $\begin{array}{l}-0.012 \\
(0.012)\end{array}$ & $\begin{array}{l}0.014 \\
(0.012)\end{array}$ \\
\hline $\begin{array}{l}\text { Capital controls } \\
\text { (capital account) }\end{array}$ & $\begin{array}{l}-0.013 \\
(0.011)\end{array}$ & $\begin{array}{l}-0.014 \\
(0.010)\end{array}$ & $\begin{array}{c}0.004 \\
(0.010)\end{array}$ & $\begin{array}{l}-0.016 \\
(0.019)\end{array}$ & $\begin{array}{l}-0.017 \\
(0.016)\end{array}$ \\
\hline $\begin{array}{l}\text { Dummy for oil- } \\
\text { exporting countries }\end{array}$ & $\begin{array}{l}\cdots \\
\cdots\end{array}$ & $\begin{array}{l}\cdots \\
\cdots\end{array}$ & $\begin{array}{l}\cdots \\
\cdots\end{array}$ & $\begin{array}{l}\cdots \\
\cdots\end{array}$ & $\begin{array}{l}\cdots \\
\cdots\end{array}$ \\
\hline $\begin{array}{l}\text { Significant time } \\
\text { dummies }\end{array}$ & None & $\begin{array}{l}81-85 \\
91-95\end{array}$ & None & $81-85$ & $\begin{array}{l}76-80,81-85 \\
86-90,91-95\end{array}$ \\
\hline $\begin{array}{l}\text { Rsquared } \\
\text { Number of observations }\end{array}$ & $\begin{array}{l}0.21 \\
317\end{array}$ & $\begin{array}{l}0.12 \\
249\end{array}$ & $\begin{array}{l}0.22 \\
82\end{array}$ & $\begin{array}{l}0.14 \\
235\end{array}$ & $\begin{array}{l}0.20 \\
167\end{array}$ \\
\hline Hausman test statistic & $\begin{array}{l}24.81 \\
{[0.0245]}\end{array}$ & $\begin{array}{l}36.41 \\
{[0.0005]}\end{array}$ & $\begin{array}{l}12.00 \\
{[0.5274]}\end{array}$ & $\begin{array}{l}18.17 \\
{[0.1512]}\end{array}$ & $\begin{array}{l}46.21 \\
{[0.0000]}\end{array}$ \\
\hline
\end{tabular}

Notes: The dependent and independent variables are non-overlapping 5-year averages of the corresponding annual variables. Standard errors are reported in parentheses. The symbols *,**, and *** indicate statistical significance at the 10 percent, 5 percent, and 1 percent levels, respectively. The last row shows Hausman test statistics for random effects versus fixed effects specifications. P-values are reported in square brackets. 
Table 5. Second Stage Regressions Using Estimated Fixed Effects

\begin{tabular}{|c|c|c|c|c|c|}
\hline & Full Sample & $\begin{array}{c}\text { Full Sample } \\
\text { Excluding } \\
\text { Africa }\end{array}$ & $\begin{array}{l}\text { Industrial } \\
\text { Countries }\end{array}$ & $\begin{array}{c}\text { Developing } \\
\text { Countries }\end{array}$ & $\begin{array}{c}\text { Developing } \\
\text { Countries } \\
\text { Excluding } \\
\text { Africa } \\
\end{array}$ \\
\hline Terms of trade volatility & $\begin{array}{l}0.037 * \\
(0.021)\end{array}$ & $\begin{array}{l}0.158 * * \\
(0.060)\end{array}$ & $\begin{array}{c}0.106 \\
(0.285)\end{array}$ & $\begin{array}{l}0.059 * \\
(0.034)\end{array}$ & $\begin{array}{c}0.029 \\
(0.093)\end{array}$ \\
\hline Average GDP growth & $\begin{array}{c}0.226 \\
(0.178)\end{array}$ & $\begin{array}{c}0.492 \\
(0.391)\end{array}$ & $\begin{array}{c}0.688 \\
(1.597)\end{array}$ & $\begin{array}{l}0.483 * * \\
(0.208)\end{array}$ & $\begin{array}{l}1.303 * * \\
(0.564)\end{array}$ \\
\hline Openness ratio & $\begin{array}{c}0.013 \\
(0.017)\end{array}$ & $\begin{array}{l}0.063 * * \\
(0.023)\end{array}$ & $\begin{array}{c}0.049 \\
(0.074)\end{array}$ & $\begin{array}{c}0.011 \\
(0.021)\end{array}$ & $\begin{array}{c}0.015 \\
(0.057)\end{array}$ \\
\hline Human capital $(\log H / L)$ & $\begin{array}{l}-0.059 * * \\
(0.022)\end{array}$ & $\begin{array}{l}-0.165 * * * \\
(0.026)\end{array}$ & $\begin{array}{l}-0.136 * * \\
(0.057)\end{array}$ & $\begin{array}{l}-0.034 \\
(0.034)\end{array}$ & $\begin{array}{l}-0.143 * * \\
(0.067)\end{array}$ \\
\hline $\begin{array}{l}\text { Relative price of } \\
\text { physical capital }\end{array}$ & $\begin{array}{l}-0.016 \\
(0.009)\end{array}$ & $\begin{array}{l}-0.016 \\
(0.013)\end{array}$ & $\begin{array}{l}-0.019 \\
(0.045)\end{array}$ & $\begin{array}{c}0.005 \\
(0.009)\end{array}$ & $\begin{array}{l}0.066 * * \\
(0.023)\end{array}$ \\
\hline $\begin{array}{l}\text { Rsquared } \\
\text { Number of observations }\end{array}$ & $\begin{array}{l}0.28 \\
56\end{array}$ & $\begin{array}{l}0.78 \\
45\end{array}$ & $\begin{array}{l}0.49 \\
16\end{array}$ & $\begin{array}{l}0.22 \\
40\end{array}$ & $\begin{array}{l}0.51 \\
29\end{array}$ \\
\hline
\end{tabular}

Notes: The dependent variable is the set of estimated fixed effects corresponding to the regressions in the 5 columns of Table 4. The human capital variable is from Hall and Jones (1999). The relative price of capital is the price of total investment divided by the price of consumption and expressed relative to this ratio for the United States. These data are from Jones (1994). Robust standard errors are reported in parentheses. The symbols *, **, and *** indicate statistical significance at the 10 percent, 5 percent, and 1 percent levels, respectively. 
Table A1. Current Account Regressions with Controls for Foreign Aid (Dependent Variable -- Current Account to GDP Ratio)

\begin{tabular}{|c|c|c|c|c|}
\hline & \multicolumn{2}{|r|}{ OLS } & \multicolumn{2}{|c|}{ Fixed Effects } \\
\hline & $\begin{array}{c}\text { Developing } \\
\text { Countries }\end{array}$ & $\begin{array}{c}\text { Developing Countries } \\
\text { Excluding Africa }\end{array}$ & $\begin{array}{c}\text { Developing } \\
\text { Countries }\end{array}$ & $\begin{array}{c}\text { Developing Countries } \\
\text { Excluding Africa }\end{array}$ \\
\hline $\begin{array}{l}\text { Govt. budget balance } \\
\text { (ratio to GDP) }\end{array}$ & $\begin{array}{l}0.347 * * * \\
(0.062)\end{array}$ & $\begin{array}{l}0.180 * * * \\
(0.064)\end{array}$ & $\begin{array}{l}0.434 * * * \\
(0.103)\end{array}$ & $\begin{array}{l}0.166^{*} \\
(0.100)\end{array}$ \\
\hline NFA to GDP ratio & $\begin{array}{l}0.038 * * * \\
0.007\end{array}$ & $\begin{array}{l}0.036^{* * * *} \\
0.007)\end{array}$ & $\begin{array}{l}0.029 * * * \\
(0.010)\end{array}$ & $\begin{array}{l}0.026^{* * * *} \\
(0.009)\end{array}$ \\
\hline Relative income & $\begin{array}{l}-0.133 \\
(0.087)\end{array}$ & $\begin{array}{l}-0.000 \\
(0.006)\end{array}$ & $\begin{array}{l}-0.084 \\
(0.243)\end{array}$ & $\begin{array}{l}-0.195 \\
(0.220)\end{array}$ \\
\hline $\begin{array}{l}\text { Relative income } \\
\text { squared }\end{array}$ & $\begin{array}{l}0.278^{*} \\
(0.149)\end{array}$ & $\begin{array}{c}0.119 \\
(0.149)\end{array}$ & $\begin{array}{c}0.230 \\
(0.332)\end{array}$ & $\begin{array}{c}0.380 \\
(0.312)\end{array}$ \\
\hline $\begin{array}{l}\text { Relative dependency ratio } \\
\quad \text { (young) }\end{array}$ & $\begin{array}{l}-0.000 \\
(0.026)\end{array}$ & $\begin{array}{l}-0.010 \\
(0.031)\end{array}$ & $\begin{array}{l}-0.006 \\
(0.079)\end{array}$ & $\begin{array}{l}-0.111 \\
(0.073)\end{array}$ \\
\hline $\begin{array}{l}\text { Relative dependency ratio } \\
\text { (old) }\end{array}$ & $\begin{array}{c}0.056 \\
(0.163)\end{array}$ & $\begin{array}{c}0.135 \\
(0.164)\end{array}$ & $\begin{array}{l}-0.070 \\
(0.641)\end{array}$ & $\begin{array}{c}0.794 \\
(0.626)\end{array}$ \\
\hline Financial deepening & $\begin{array}{l}0.035 * * * \\
(0.012)\end{array}$ & $\begin{array}{l}0.025^{*} \\
(0.014)\end{array}$ & $\begin{array}{l}-0.075^{*} \\
(0.039)\end{array}$ & $\begin{array}{l}-0.061 \\
(0.038)\end{array}$ \\
\hline $\begin{array}{l}\text { Terms of trade } \\
\text { volatility }\end{array}$ & $\begin{array}{c}0.019 \\
(0.021)\end{array}$ & $\begin{array}{l}0.031 \\
(0.025)\end{array}$ & $\begin{array}{l}\cdots \\
\cdots\end{array}$ & $\begin{array}{l}\cdots \\
\cdots\end{array}$ \\
\hline Average GDP growth & $\begin{array}{l}-0.021 \\
(0.164)\end{array}$ & $\begin{array}{l}0.166 \\
(0.173)\end{array}$ & $\begin{array}{l}\cdots \\
\cdots\end{array}$ & $\begin{array}{l}\cdots \\
\cdots\end{array}$ \\
\hline Openness ratio & $\begin{array}{l}-0.014 \\
(0.012)\end{array}$ & $\begin{array}{l}-0.022 \\
(0.017)\end{array}$ & $\begin{array}{l}\cdots \\
\cdots\end{array}$ & $\begin{array}{l}\cdots \\
\cdots\end{array}$ \\
\hline $\begin{array}{l}\text { Capital controls } \\
\text { (current account) }\end{array}$ & $\begin{array}{c}0.003 \\
(0.007)\end{array}$ & $\begin{array}{c}0.004 \\
(0.007)\end{array}$ & $\begin{array}{c}0.007 \\
(0.013)\end{array}$ & $\begin{array}{c}0.008 \\
(0.012)\end{array}$ \\
\hline $\begin{array}{l}\text { Capital controls } \\
\text { (capital account) }\end{array}$ & $\begin{array}{c}0.012 \\
(0.010)\end{array}$ & $\begin{array}{c}0.009 \\
(0.009)\end{array}$ & $\begin{array}{c}0.004 \\
(0.020)\end{array}$ & $\begin{array}{l}-0.002 \\
(0.016)\end{array}$ \\
\hline $\begin{array}{l}\text { Dummy for oil- } \\
\text { exporting countries }\end{array}$ & $\begin{array}{l}0.015 \\
(0.011)\end{array}$ & $\begin{array}{c}0.023 \\
(0.010)\end{array}$ & $\begin{array}{l}\cdots \\
\cdots\end{array}$ & $\begin{array}{l}\cdots \\
\cdots\end{array}$ \\
\hline Foreign aid/GDP & $\begin{array}{l}-0.202 * * * \\
(0.073)\end{array}$ & $\begin{array}{c}0.049 \\
(0.106)\end{array}$ & $\begin{array}{l}-0.096 \\
(0.156)\end{array}$ & $\begin{array}{c}0.019 \\
(0.164)\end{array}$ \\
\hline $\begin{array}{l}\text { Significant time } \\
\text { dummies }\end{array}$ & $81-85$ & $81-85$ & None & $81-85$ \\
\hline Rsquared & 0.49 & 0.49 & 0.22 & 0.08 \\
\hline Number of observations & 206 & 142 & 206 & 142 \\
\hline
\end{tabular}

Notes: The dependent and independent variables are non-overlapping 5-year averages of the corresponding annual variables Standard errors are reported in parentheses. The symbols *,**, and *** indicate statistical significance at the 10 percent, 5 percent, and 1 percent levels, respectively. 
Table A2. Panel Regressions for Annual Data, OLS Specification with Time Effects (Dependent Variable --Current Account to GDP Ratio)

\begin{tabular}{|c|c|c|c|c|c|}
\hline & Full Sample & $\begin{array}{c}\text { Full Sample } \\
\text { Excluding } \\
\text { Africa }\end{array}$ & $\begin{array}{l}\text { Industrial } \\
\text { Countries } \\
\end{array}$ & $\begin{array}{c}\text { Developing } \\
\text { Countries }\end{array}$ & $\begin{array}{c}\text { Developing } \\
\text { Countries } \\
\text { Excluding } \\
\text { Africa } \\
\end{array}$ \\
\hline $\begin{array}{l}\text { Govt. budget balance } \\
\text { (ratio to GDP) }\end{array}$ & $\begin{array}{l}0.173^{* * *} \\
(0.034)\end{array}$ & $\begin{array}{l}0.121 * * * \\
(0.027)\end{array}$ & $\begin{array}{l}0.076 * * \\
(0.034)\end{array}$ & $\begin{array}{l}0.213 * * * \\
(0.041)\end{array}$ & $\begin{array}{l}0.167 * * * \\
(0.036)\end{array}$ \\
\hline NFA to GDP ratio & $\begin{array}{l}0.023^{* * *} \\
(0.007)\end{array}$ & $\begin{array}{l}0.024 * * * \\
(0.007)\end{array}$ & $\begin{array}{l}0.052 * * \\
(0.012)\end{array}$ & $\begin{array}{l}0.020 * * \\
(0.009)\end{array}$ & $\begin{array}{l}0.016 * \\
(0.010)\end{array}$ \\
\hline Relative income & $\begin{array}{c}0.004 \\
(0.022)\end{array}$ & $\begin{array}{c}0.010 \\
(0.020)\end{array}$ & $\begin{array}{c}0.012 \\
(0.049)\end{array}$ & $\begin{array}{l}-0.054 * \\
(0.031)\end{array}$ & $\begin{array}{l}-0.049 * \\
(0.031)\end{array}$ \\
\hline $\begin{array}{l}\text { Relative income } \\
\text { squared }\end{array}$ & $\begin{array}{l}-0.001 \\
(0.018)\end{array}$ & $\begin{array}{l}-0.001 \\
(0.017)\end{array}$ & $\begin{array}{l}-0.017 \\
(0.038)\end{array}$ & $\begin{array}{l}0.114 * * \\
(0.045)\end{array}$ & $\begin{array}{l}0.114 * * \\
(0.047)\end{array}$ \\
\hline $\begin{array}{l}\text { Relative dependency ratio } \\
\quad \text { (young) }\end{array}$ & $\begin{array}{l}-0.003 \\
(0.012)\end{array}$ & $\begin{array}{l}-0.001 \\
(0.012)\end{array}$ & $\begin{array}{l}-0.042 \\
(0.033)\end{array}$ & $\begin{array}{l}-0.005 \\
(0.014)\end{array}$ & $\begin{array}{l}-0.008 \\
(0.017)\end{array}$ \\
\hline $\begin{array}{l}\text { Relative dependency ratio } \\
\text { (old) }\end{array}$ & $\begin{array}{c}0.041 \\
(0.045)\end{array}$ & $\begin{array}{c}0.041 \\
(0.045)\end{array}$ & $\begin{array}{l}-0.012 \\
(0.061)\end{array}$ & $\begin{array}{c}0.049 \\
(0.080)\end{array}$ & $\begin{array}{c}0.021 \\
(0.093)\end{array}$ \\
\hline $\begin{array}{l}\text { Financial deepening } \\
\text { (M2/GDP) }\end{array}$ & $\begin{array}{l}0.010 * * * \\
(0.005)\end{array}$ & $\begin{array}{c}0.006 \\
(0.005)\end{array}$ & $\begin{array}{l}-0.004 \\
(0.007)\end{array}$ & $\begin{array}{l}0.015 * * \\
(0.007)\end{array}$ & $\begin{array}{c}0.012 \\
(0.010)\end{array}$ \\
\hline $\begin{array}{l}\text { Terms of trade } \\
\text { volatility }\end{array}$ & $\begin{array}{c}0.015 \\
(0.010)\end{array}$ & $\begin{array}{l}0.019 * \\
(0.010)\end{array}$ & $\begin{array}{l}-0.016 \\
(0.028)\end{array}$ & $\begin{array}{c}0.018 * \\
(0.010)\end{array}$ & $\begin{array}{c}0.018 \\
(0.011)\end{array}$ \\
\hline Average GDP growth & $\begin{array}{c}0.047 \\
(0.087)\end{array}$ & $\begin{array}{c}0.045 \\
(0.085)\end{array}$ & $\begin{array}{l}0.793 * * \\
(0.312)\end{array}$ & $\begin{array}{c}0.027 \\
(0.094)\end{array}$ & $\begin{array}{c}0.007 \\
(0.099)\end{array}$ \\
\hline Openness ratio & $\begin{array}{c}0.003 \\
(0.004)\end{array}$ & $\begin{array}{c}0.007 * \\
(0.004)\end{array}$ & $\begin{array}{l}-0.006 \\
(0.010)\end{array}$ & $\begin{array}{l}-0.003 \\
(0.005)\end{array}$ & $\begin{array}{l}-0.002 \\
(0.005)\end{array}$ \\
\hline $\begin{array}{l}\text { Capital controls } \\
\text { (current account) }\end{array}$ & $\begin{array}{c}0.001 \\
(0.003)\end{array}$ & $\begin{array}{c}0.003 \\
(0.003)\end{array}$ & $\begin{array}{l}-0.002 \\
(0.004)\end{array}$ & $\begin{array}{c}0.007 \\
(0.004)\end{array}$ & $\begin{array}{c}0.004 \\
(0.004)\end{array}$ \\
\hline $\begin{array}{l}\text { Capital controls } \\
\text { (capital account) }\end{array}$ & $\begin{array}{l}-0.003 \\
(0.003)\end{array}$ & $\begin{array}{l}-0.003 \\
(0.003)\end{array}$ & $\begin{array}{c}0.002 \\
(0.003)\end{array}$ & $\begin{array}{l}-0.005 \\
(0.004)\end{array}$ & $\begin{array}{l}-0.006 \\
(0.005)\end{array}$ \\
\hline $\begin{array}{l}\text { Dummy for oil- } \\
\text { exporting countries }\end{array}$ & $\begin{array}{c}0.007 \\
(0.007)\end{array}$ & $\begin{array}{l}0.009 \\
(0.007)\end{array}$ & $\begin{array}{l}\cdots \\
\cdots\end{array}$ & $\begin{array}{c}0.004 \\
(0.007)\end{array}$ & $\begin{array}{c}0.007 \\
(0.007)\end{array}$ \\
\hline $\begin{array}{l}\text { Lagged CA to GDP } \\
\text { Ratio }\end{array}$ & $\begin{array}{l}0.566 * * * \\
(0.032)\end{array}$ & $\begin{array}{l}0.573 * * * \\
(0.035)\end{array}$ & $\begin{array}{l}0.642 * * * \\
(0.048)\end{array}$ & $\begin{array}{l}0.541 * * * \\
(0.035)\end{array}$ & $\begin{array}{l}0.536 * * * \\
(0.040)\end{array}$ \\
\hline $\begin{array}{l}\text { Lagged change in real } \\
\text { exchange rate }\end{array}$ & $\begin{array}{l}-0.003 \\
(0.007)\end{array}$ & $\begin{array}{l}-0.009 \\
(0.007)\end{array}$ & $\begin{array}{l}-0.011 * * \\
(0.004)\end{array}$ & $\begin{array}{l}-0.003 \\
(0.008)\end{array}$ & $\begin{array}{l}-0.011 \\
(0.009)\end{array}$ \\
\hline $\begin{array}{l}\text { Rsquared } \\
\text { Number of observations }\end{array}$ & $\begin{array}{l}0.54 \\
1469\end{array}$ & $\begin{array}{r}0.53 \\
1081\end{array}$ & $\begin{array}{l}0.69 \\
378\end{array}$ & $\begin{array}{l}0.53 \\
1091\end{array}$ & $\begin{array}{l}0.51 \\
703\end{array}$ \\
\hline
\end{tabular}

Notes: Robust standard errors are reported in parentheses. The symbols *, **, and *** indicate statistical significance at the 10 percent, 5 percent, and 1 percent levels, respectively. 
Figure 1. Gurrent Accounts \& NFAs, Cross Section
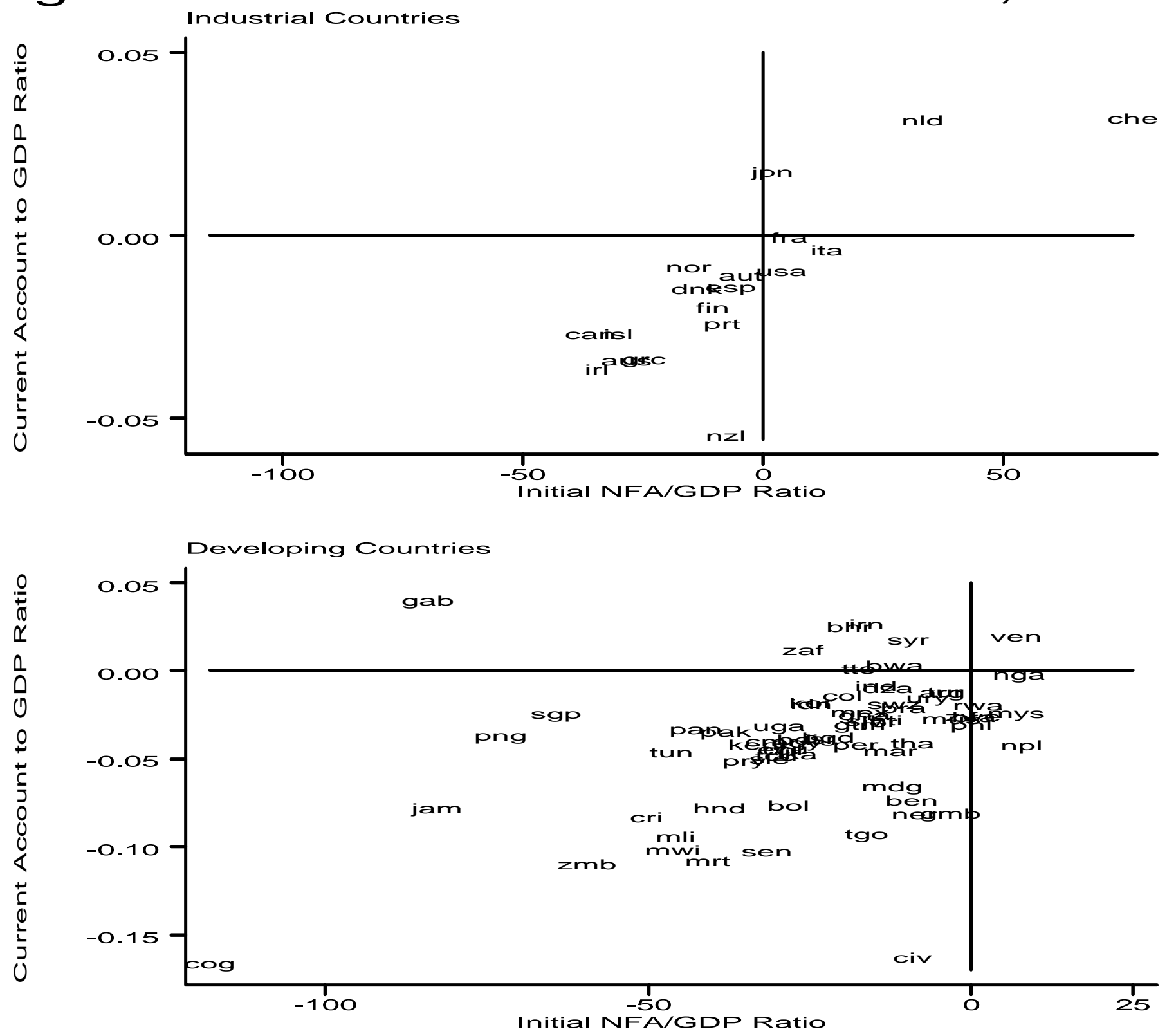
Fig. 2. Current Accounts and Relative Income, Cross Section

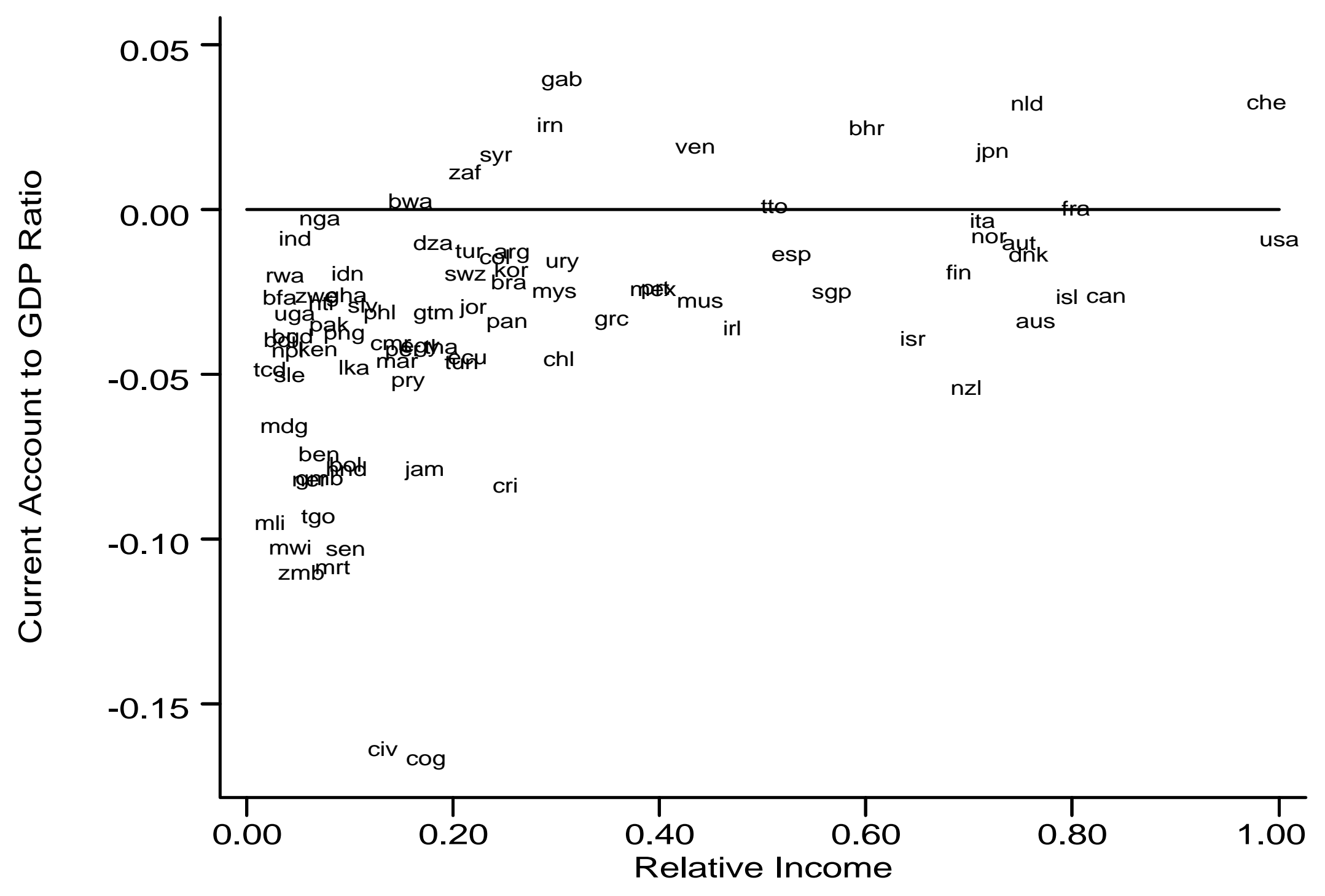


Fig. 3. Actual, Fitted Values of CA/GDP Ratios Industrial Countries
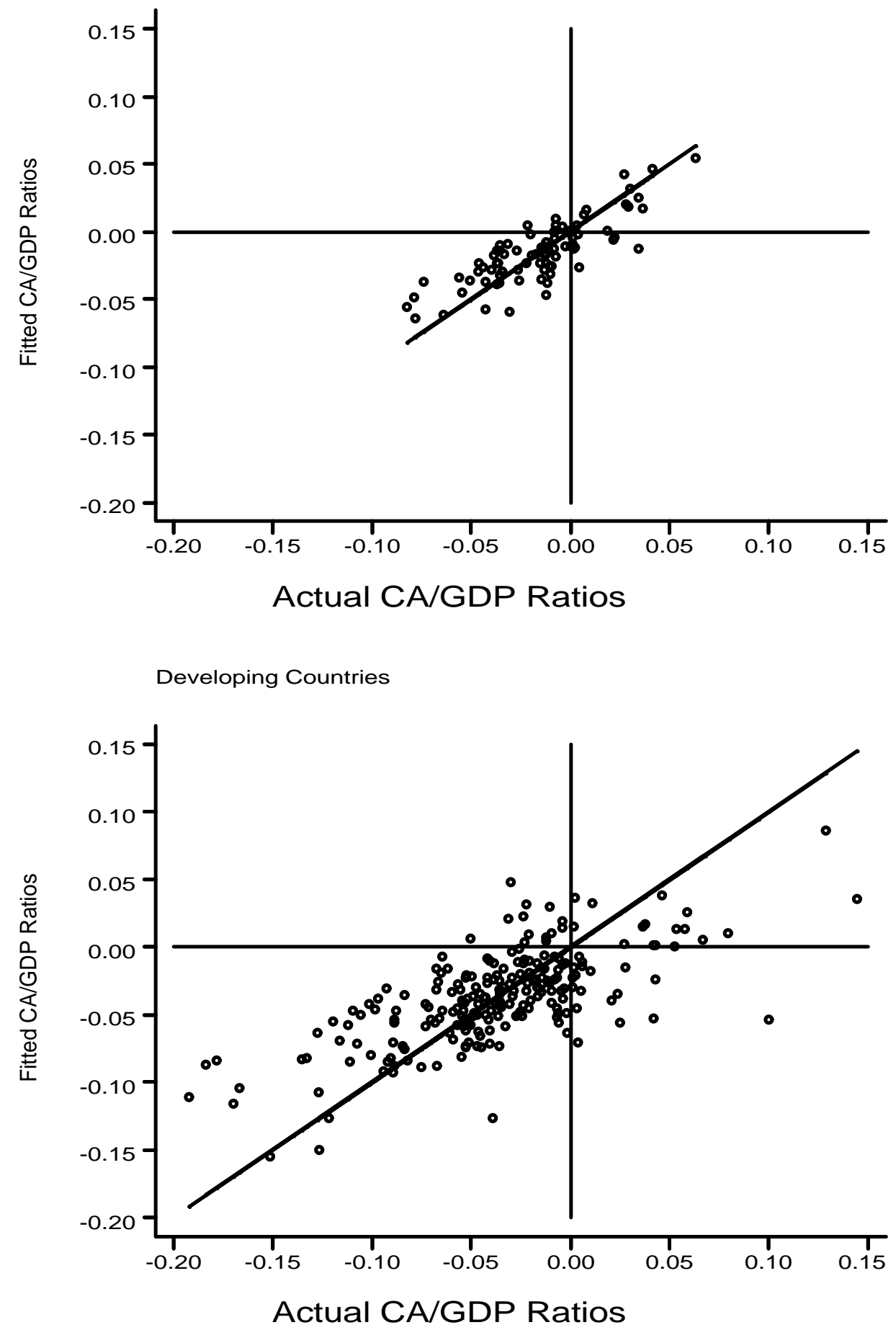

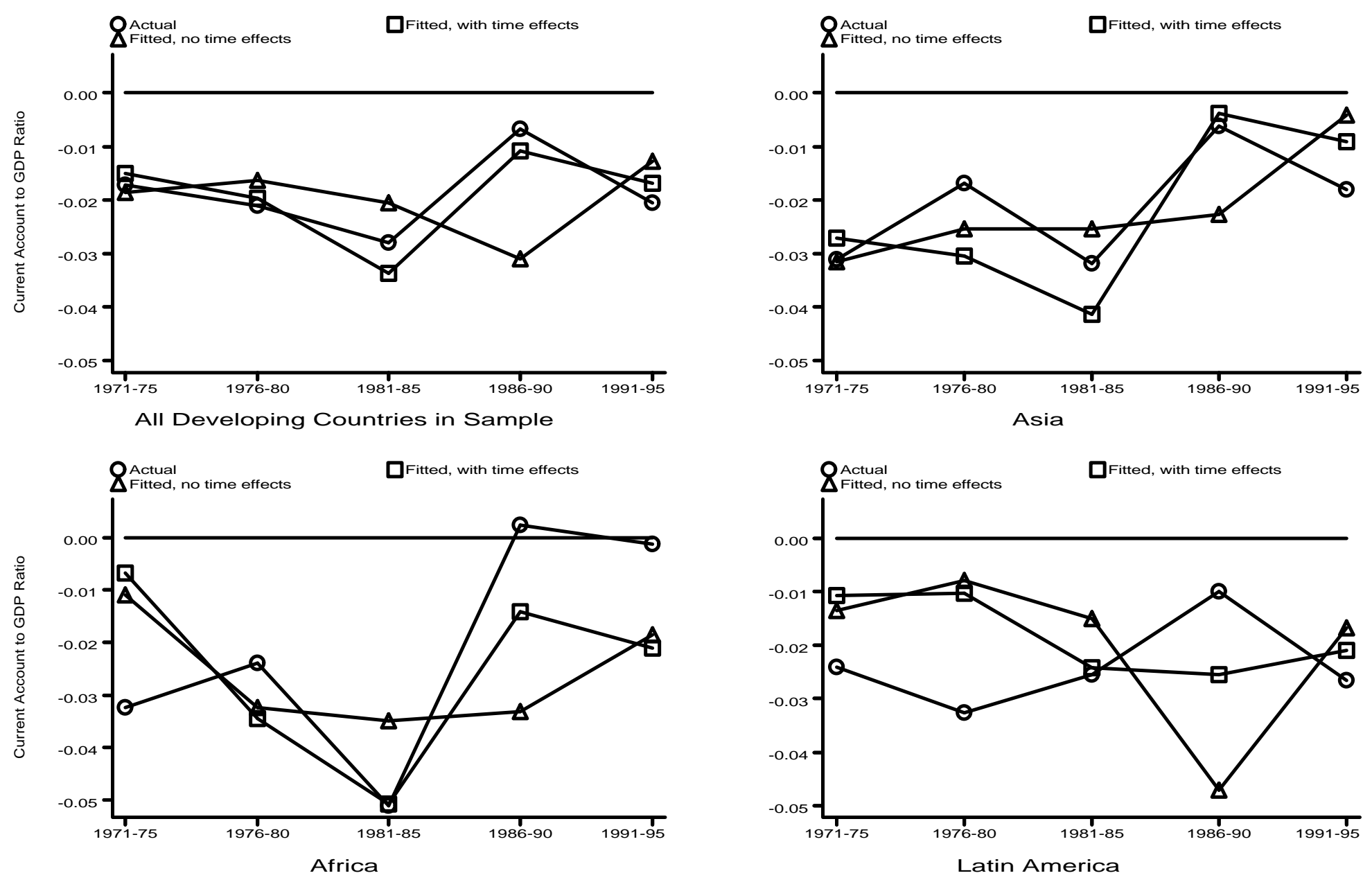

Fig. 4. Actual, Fitted Current Accounts for Developing Country Blocks 